\title{
1. Understanding the pillars of Takaful
}

\subsection{CONCEPT OF TAKAFUL}

The doctrine of al-Takaful, as adopted by the Islamic insurance operators of today, is an adequate alternative to that of regular insurance services. Insurance services may have a place in Islamic finance if they are approved by the Shari'ah, based on shared responsibility, mutual cooperation and solidarity, ${ }^{1}$ in order to protect someone against a well-defined risk.

The term Takaful is a noun (مصدر) which is derived from the root of the word Kafl (كفل), which means guarantee or responsibility, while Takaful (تكافل), whose chief characteristic is al-Musharakah (المشاركة), means sharing. Thus, the word Takaful stands for shared responsibility, shared guarantee, collective assurance, and mutual undertakings. ${ }^{2}$ Technically, Takaful (تكافل) from the economic point of view means a mutual guarantee or assurance, based on the principles of al-'Aqd provided by a group of people living in the same society, against a well-defined risk or catastrophe affecting one's life, property or any possession of value. Hence, Takaful is better known as cooperative insurance with mutual agreement. ${ }^{3}$

In Takaful, there are usually four parties involved, namely: (1) participant; (2) operator; (3) insured; and (4) beneficiary. ${ }^{4}$ The nature of Takaful is that in a society, anybody who has legal capacity may contribute an amount of money to a mutual cooperative fund. This is with a view to ensuring material security against a well-defined risk, probably related to another's life or property. Thus, those who contribute to the mutual fund are known as participants, while those who are among the participants who face a risk and are assisted by the fund are known as the insured. Those who actually benefit from the fund are known as the beneficiaries of a cooperative fund. The monetary contribution made by the participants to the fund is known as a mutual contribution. The fund is managed by a registered or licensed entity as a corporation ${ }^{5}$ known as a Takaful operator. The operator binds themself bilaterally to manage the fund according to Shari'ah principles, and also to provide reasonable financial security against a loss or damage as a result of a well-defined risk. Furthermore, the financial contribution made by the participants is put into two funds: one is an investment fund according to the principles of al-Mudharabah 
(profit and loss sharing), while the other is treated as charity, according to the principles of al-Tabarru' ${ }^{6}$ In Malaysia, the two funds are termed Participants' Account (PA) and Participants' Special Account (PSA) respectively.

To illustrate further, on the central idea of Takaful practice, much emphasis is placed on the issues of "joint benefit", "shared responsibility" and "shared guarantee". Accordingly, the distinct character of this form of mutual financial scheme is that the contract is based on the Divine Virtues of cooperation, mutual help, shared responsibility and benefit, brotherhood and solidarity. In addition, all aspects of the contract should be transparent to all parties involved therein. ${ }^{7}$ The basic motive for Takaful is to bring equity to all parties involved while profits should not be the prime objective. On the contrary, helping other participants who encounter catastrophe, in a way sharing the misfortune, as well as sharing possible profits, is the actual goal. The management of Takaful funds, therefore, is to exercise prudence when making investment decisions, and not to use the funds for high returns in exchange for high risk. ${ }^{8}$

To understand better the nature of the Takaful industry, one should consider the element of al-Tabarru' in accordance with the principle of the joint guarantee for helping other society members. Each certificate holder willingly agrees to give a portion of their paid contribution in favor of other participants who are struck by a misfortune and may be in need of financial aid. This may include taking responsibility for safeguarding a deceased participant's dependents from a well-defined risk. This is the essence of family Takaful as justified by Shari' ah principles. ${ }^{9}$ The beneficiaries, in turn, must accept the true spirit of Tabarru' and should honestly realize that the amount of money paid to them came from their fellow participants. As such, they should try not to realize any material gain or be involved in selfprofiting activities at the cost of other participants.

In the case of family Takaful, the participant normally appoints a person as a nominee who shall act as a mere trustee. This person will distribute Takaful benefits among the legal heirs of the deceased participant. The distribution of benefits in such a case will take place in accordance with the principles of Faraid (inheritance). ${ }^{10}$ In order to claim benefits in a family Takaful, only a proof of the death of the certificate holder is required. The cause of death, whether by natural causes or accident or even unlawful reasons does not matter, as this is the will of Allah (swt) who determines the death of all creatures. This has been clarified by Allah (swt) in the following verse of the Holy Qur'an:

"Nor can a soul die except by Allah (swt)'s leave, the term being fixed as by writing."11 
We must note here that in the event of suicide or death as a result of a crime, the deceased participant is solely accountable to Allah (swt) for his/ her own act. ${ }^{12}$ So, the beneficiaries in this situation should not be deprived of their legitimate claim on the certificate as a result of the participant's criminal act.

In the event that the participant is still alive upon the maturity of the certificate, they have the right to claim from the operator the total amount of paid contributions, together with a share of the possible profits made from the contributions. In addition, they will also receive bonus pay-outs and dividends according to the relevant policy. Should the participant die before the maturity of the certificate, the nominee shall have the right to claim the total paid contributions, the share of the profits made, bonuses and dividends, and also a donation from the company's Tabarru' fund.

The concept of the contract of al-Mudharabah, also inherent in Takaful, is that all participants must agree to share the profits from the undertaking. Each concerned party in the Takaful contract, that is, the operator, the participants, marketing officers or agents and management, will take a share from the profit of the business, which is financed by the participants' paid contributions. The marketing officer or agent who sells a family Takaful certificate will not be paid commission, but should receive a salary as agreed upon between the marketing officer and the operator, on the basis of an al-Ijarah or an al-Wakalah contract. In addition, they may have the right to share profits made by the company as well as dividends in accordance with the company's policy, as does the management. The fact that the management receives possible profits should give the policyholders financial comfort and therefore they will have more confidence in the fund.

\subsection{ORIGIN AND DEVELOPMENT OF TAKAFUL}

As discussed, the central idea of a Takaful contract is that it is a financial agreement of a mutual cooperation between two parties in order to protect one of the parties from an unexpected future risk with material consequences. Thus, the insured pays a certain amount of money known as the contribution (premium) to the insurer. This is realized with a mutual agreement that the insurer is under a legal obligation to provide the insured with financial protection against unexpected loss for an agreed period of time. However, in a case whereby a possible loss does not occur within a specified period, the insured is entitled to the whole amount of the paid premiums as well as a share of possible profits based on the principle of al-Mudharabah ${ }^{13}$ financing technique. In such a transaction, both the insurer and the insured are mutually helping each other in terms of financial cooperation. 
Such mutual benefit cooperation between both parties is certainly in line with the Qur'anic doctrine of mutual cooperation as Allah (swt) commanded to this effect:

"And co-operate ye one another in righteousness and piety."14

Under the Islamic teachings, the commandment to practice mutual cooperation is not general. There is a limit to it, as Allah (swt) has further prohibited people from cooperating in any way that involves sinful elements. Allah (swt) says to this effect:

\section{"And do not co-operate in sin and rancor."15}

Based on the above verse of the Holy Qur'an, we could reach the conclusion that the practice of an insurance business in general will only be in harmony with the Islamic concept of mutual cooperation if the underlying transaction is performed based on the principle of Mudharabah. That means that the insurance operation is permissible in the eyes of Allah (swt) and carried out based on the noble and sincere intention of the involved parties to protect the insured from unexpected future financial risk with tangible consequences. Hence, in order for the insurance transaction to become valid and enforceable, it should be free from unlawful elements such as usury or fraud. ${ }^{16}$

\subsubsection{Development in Stages}

Even though the exact period when insurance operations and practices began in Islam is not known, based on the nature of the insurance contracts today it may be concluded that insurance transactions were practiced since before the time of the Holy Prophet Muhammad (saw). Then they were gradually developed until the beginning of the 19th century, when a Hanafi lawyer named Ibn Abidin (1784-1836) became the first Islamic scholar to come up with the meaning, concept and legal entity of an insurance contract. ${ }^{17}$ As a result, we can observe today a number of insurance companies that are operating based on the divine principles. This development of the Islamic insurance industry could be classified into the following six stages:

\section{Practices of al-'Aqilah among the ancient Arab tribes}

There are many sources justifying the fact that the nature of insurance practice originated from the ancient Arabs' practices. ${ }^{18}$ Then it was a custom among the tribes of Arabs that if any member of a tribe was killed 
by a member of another tribe, the beneficiaries of the victim would be paid an amount of "blood" money as compensation by the close relatives of the killer. Those close relatives of the killer were addressed as al-' Aqilah, ${ }^{19}$ which means those who were supposed to pay the blood money ${ }^{20}$ on behalf of the killer. The word al-'Aqilah means Asaba, which denotes paternal relatives of the killer. ${ }^{21}$ Therefore, the central idea of the doctrine "Aqilah" was practiced among the ancient Arab tribes. Willingness of the ancient Arabs at that time to pay compensation seemed to be a kind of financial protection for the beneficiaries of the deceased against unexpected death caused by another person.

\section{Practices of the Holy Prophet (saw)}

The development of insurance practices during the time of the Holy Prophet (saw) could have originated from two sources:

1. The acceptance of the ancient Arabs' practices of al-Aqilah:

The Prophet (saw) himself had accepted the concept of al-'Aqilah as practiced by the ancient Arab tribes. This could well be justified from the numerous verdicts or Sunnah of the Prophet (saw). ${ }^{22}$ In one of the disputes, the Holy Prophet (saw) decided as follows:

"Narrated by Abu Hurairah (RA), he said that once two women from Huzail clashed when one of them hit the other with a stone which killed her and the baby in the victim's womb. The heirs of the victim brought an action to the court of the Holy Prophet (saw) who gave a verdict that the compensation for the foetus to be a male or female slave while the compensation for the killed woman is a blood money (Dyat) to be paid by the 'Aqilah' (the relatives of the father's side) of the killer." 23

2. The relevant legislation which passed in the first Constitution of Medina in $622 \mathrm{CE}(1 \mathrm{AH})$ :

The first constitution in the Muslim world, which was prepared by the Holy Prophet Muhammad (saw) shortly after the movement to Medina in $622 \mathrm{BC}$, for the people there such as the Muhajireen, the Ansar, the Jews and the Christians, had an element of social insurance, which appeared as three modules. ${ }^{24}$

The first module was through the practice of Dyat: Dyat or blood money was supposed to be paid mutually by the al-'Aqilah to the heir of the victim in order to protect the killer from a legal burden. ${ }^{25}$ The Holy Prophet (saw) ruled in article 3 of the above constitution of Medina that:

“The immigrants among 'Quraish' shall be responsible for their word and shall pay their blood money in mutual collaboration." 26 
Similarly, Banu Awf, Banu Harith and other social groups living in Medina at that time were also obliged to pay blood money in mutual collaboration relying on the doctrine of al-'Aqilah as ruled in the constitution. ${ }^{27}$

The second module was through the payment of Fidyah (ransom): the Holy Prophet (saw) had also included a provision in the first constitution concerning rescuing the life of the prisoners. According to this provision, for any person being held as a prisoner of war by an enemy, the Aqilah of the prisoner shall contribute a ransom to be paid to the enemy in order to set the captive free. ${ }^{28}$ Such a contribution could well be considered as another form of social insurance. The Holy Prophet (saw) mentioned this to this effect:

"The immigrants among the Quraish shall be responsible for ... releasing the prisoners by way of paying their ransom, so that the mutual collaboration among the believers be in accordance with the principles of goodness and justice."29

The above rule was also applicable to other groups such as Banu Harith, Banu Najjar, Banu Jusham and others living in the Medinan society at that time. ${ }^{30}$

The third module was from other forms of social insurance included in the first constitution. In the above respect, the society will be responsible for establishing a joint fund with a mutual understanding towards providing necessary aid for the needy, ill and poor. ${ }^{31}$

\section{Practices of the companions}

Further developments of the practice of insurance-based transactions could be discovered in the period of the second Caliph, Sayyidina Omar $(R A)$. During that period, the doctrine of Aqilah had even been encouraged by the government rulers. Sayyidina Omar $(R A)$ had commanded that a "Diwan" of Mujahideen be established in various districts and those whose names were recorded and contained in the Diwan had a mutual agreement of cooperation to contribute blood money for manslaughter committed by someone from their own tribe. ${ }^{32}$ Hence, it is presumed here that the application of the doctrine of Aqilah had further been developed during the period of the second Caliph of Islam Sayyidina Omar $(R A)$, which, hence, reflects the elements of insurance practice during that period.

\section{Developments in the 14th-17th centuries}

During the period of the 14th to the 17th centuries, the Sufi Order of the Kazeeruniyya was very popular especially in port cities in Malabar and in China. This Order served as a kind of marine travel insurance company. It had been associated with the tomb of Abu Ishaq Ibrahim IbnShahariyahb 
whose blessings were considered to be a protection against hazards during the sea voyage. ${ }^{33}$

\section{Developments in the 19th century}

During the period of the 19th century Ibn Abidin (1784-1836), a Hanafi lawyer, was the first person to discuss the idea of insurance as a legal entity. He was also the first person to discover insurance in the context of a legal constitution, being no longer a customary practice. ${ }^{34}$ Ibn Abidin's opinion of insurance practice with the form of a legal institution served as an eye-opener to many Muslims who did not accept the legality of insurance practice and it prompted Muslims to accept the idea of involvement in the insurance business. Muslims in the 19th century began to practice insurance business not only by buying insurance services from non-Muslim companies, but they also established insurance companies and became insurers themselves. ${ }^{35}$

\section{Developments in the 20th century}

In the 20th century, a well-known Islamic Law expert, Muhammad Abduh, issued two "Fatwas" mentioning that an insurance transaction is like the transaction of the al-Mudharabah financing technique, while the other was that a transaction which is similar to endowment or life insurance is legal. ${ }^{36}$

The gradual growth and development of Shari'ah-based insurance practices in the 20th century in both Muslim and non-Muslim countries is quite satisfactory despite the fact that there are still some areas to be developed in order to meet the needs of modern society. Nevertheless, it is also true that there are many scholars today who oppose the practice of insurance, especially life insurance, without proposing an alternative for the Muslim Ummah. It is undeniable that there are some elements of today's conventional insurance practices that are not recognized by the Shari'ah. This of course does not mean that insurance practices are entirely unlawful and illegal. It is suggested here that even though certain aspects of the conventional insurance practices could not be adopted by Muslims due to certain Shari'ah prohibitions, it is the responsibility of the present Islamic Scholars to be innovative and come up with alternative models of Islamic insurance which would eliminate all the elements prohibited by Islamic Law. In this respect the Muslim Ummah will be able to be protected from any form of unexpected risk and hazard. This is the desirable direction in modern societies.

The Organization of Islamic Conference (OIC) has taken the initiative to establish an international Re-Insurance Corporation. ${ }^{37}$ Today, several research studies on Shari'ah compatible insurance operations are conducted internationally in order to make insurance theory, practices and benefits well understood so that the contemporary Muslim Ummah can benefit from it. 
Nowadays, there are many Shari'ah-based insurance companies established in many countries such as Malaysia, Brunei, Singapore, Indonesia, Iran, Sudan, Saudi Arabia, Qatar, Luxembourg and Bahrain, among others. However, the debate regarding the validity of the insurance policy is still under discussion among Islamic Scholars.

Table 1.1 contains details of some of the most important Takaful companies operating globally.

In Islam, insurance policy and practice originated from the customs practiced by the ancient Arab tribes before the rise of Islam in the form of the doctrine of al-Aqilah, which was subsequently approved by the Prophet Muhammad (saw) during his lifetime in one of his decisions given against a woman from the Huzail tribe. Later, such insurance transactions were gradually practiced and were even made mandatory in some cases during the period of the second Caliph, Sayyidina $\operatorname{Omar}(R A) .{ }^{38}$

Table 1.1 Top Takaful operators/Takaful windows globally by total assets

\begin{tabular}{lcc}
\hline Name of Takaful operator & Country & $\begin{array}{c}\text { Total assets (US\$ } \\
\text { Mn, FYE 2015) }\end{array}$ \\
\hline Bimeh Iran & Iran & $\$ 3988$ \\
The Company for Cooperative Insurance & KSA & $\$ 3083$ \\
Etiqa Takaful Berhad & Malaysia & $\$ 3053$ \\
Syarikat Takaful Malaysia & Malaysia & $\$ 1755$ \\
Bupa Arabia for Cooperative Insurance & KSA & $\$ 1640$ \\
The Mediterranean and Gulf Cooperative & KSA & $\$ 1473$ \\
$\quad$ Insurance and Reinsurance Company & & \\
Islamic Arab Insurance Company (Salama) & EAU & $\$ 915$ \\
Asia Insurance Co. & Iran & $\$ 900$ \\
Takaful Ikhlas Sendirian Berhad & Malaysia & $\$ 723$ \\
Bime Alborz & Iran & $\$ 672$ \\
\hline
\end{tabular}

Source: ICD-Thomson Reuters Islamic Finance Development Report 2016.

Table 1.2 Takaful assets breakdown by fully fledged/window

\begin{tabular}{ccc}
\hline Year & Fully fledged (US\$ Bn) & Window (US\$ Bn) \\
\hline 2012 & $\$ 31.13$ & $\$ 0.49$ \\
2013 & $\$ 29.86$ & $\$ 0.61$ \\
2014 & $\$ 32.56$ & $\$ 0.83$ \\
\hline
\end{tabular}

Source: Global Advisors World Takaful Report 2016. 


\subsection{RISK MANAGEMENT: THE SYNERGIES BETWEEN ISLAMIC FINANCE AND TAKAFUL}

Risk management in the 1970s dealt with "passive risks" and focused more on the measurement of risk exposure, the reduction of the costs of insurance products and the promotion of broker-client relationships. Nevertheless, the specific risks of the insurance industry were overlooked. During the 1980s, a shift occurred towards business risk management. Thus, insurance companies performed risk assessments for market competition, rate of technological change or product liability. Then, internal processes were developed in order to respond to risk threats. Nevertheless, focus stayed on controlling possible losses and keeping the cost of insurance at a low level. Since 1995, risk management theory has been developed and encompasses a wide spectrum of risks in the risk evaluation process. Figure 1.1 is an illustration of a spectrum of insurance enterprise risks.

Risk managers today focus equally on the cost as well as the potential impacts of various risks on enterprise performance, including profitability. Nowadays, managers face a tougher and more competitive market where there is a high cost of failure and a narrow margin of "error" in decisionmaking. There are recent impressive examples of the above trend:

- BCCI 1991: $+\$ 1$ billion losses;

- Barings 1995: $+\$ 1.4$ billion losses and bankruptcy;

- LTC Management 1998: losses of $\$ 4.7$ billion in a few months and yet over $\$ 45$ billion in equity losses from sharp drop in stock price;

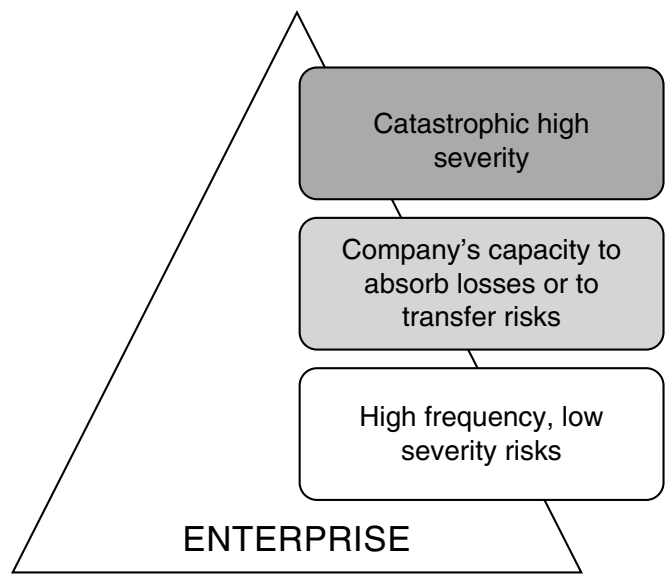

Figure 1.1 Prism of enterprise risks 
- Sumitomo Bank: $\$ 1.8$ billion commodity trading losses;

- World Trade Center September 2001: property/casualty damage and business income losses in excess of $\$ 100$ billion;

- Enron 2002: pension losses alone more than $\$ 400$ million;

- World Com 2002: accounting manipulations caused failure of public trust in the company and reduced shareholder value by $\$ 100$ billion.

In summary, the new concept in risk management is that the nature and impact of risks to the enterprise as a whole are of paramount importance. Managers who wish to create value for their companies should care less about the costs of risk mitigation and more about the total net gain in shareholder value as a result of successful risk management techniques. From a general point of view, we observe a shift of the risk management framework to an effective use of enterprises' risk capacity, a combination of companies' capacity to absorb losses from unexpected events, plus allocation of company capital that is required to transfer risks through purchase of insurance coverage.

Consequently, there is an obvious trend for decision-makers to become more informed, to perform data analysis and evaluate the possible options regarding:

- which risks to avoid;

- which risks to transfer and at what price;

- which risks to absorb and at what possible cost.

In brief, the focus is now on the Risk Adjusted Return (RAR) versus the previously used Return on Equity (ROE) or Return on Investment (ROI), which may overlook important risk factors with a huge possible impact on the enterprise.

\subsubsection{Application of Risk Management to Islamic Asset Finance}

Typically, the dynamic analysis for assessing a potential cost-effective financial deal requires the following factors to be considered (Figure 1.2).

If we utilize a spectrum approach to assessing risks of asset financing, then we might map the risks of a financial transaction/deal as shown in Figure 1.3.

\subsubsection{Synergies of Islamic Finance with Takaful}

Potentially there are two main areas where Islamic finance and Takaful might merge and give cooperative results: 


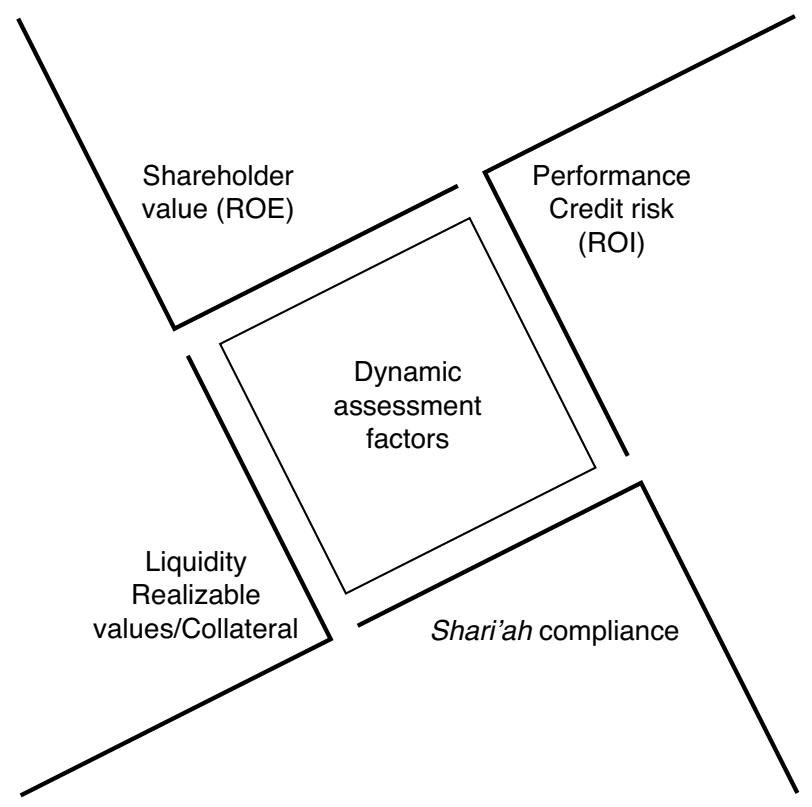

Figure 1.2 Spectrum of enterprise risks

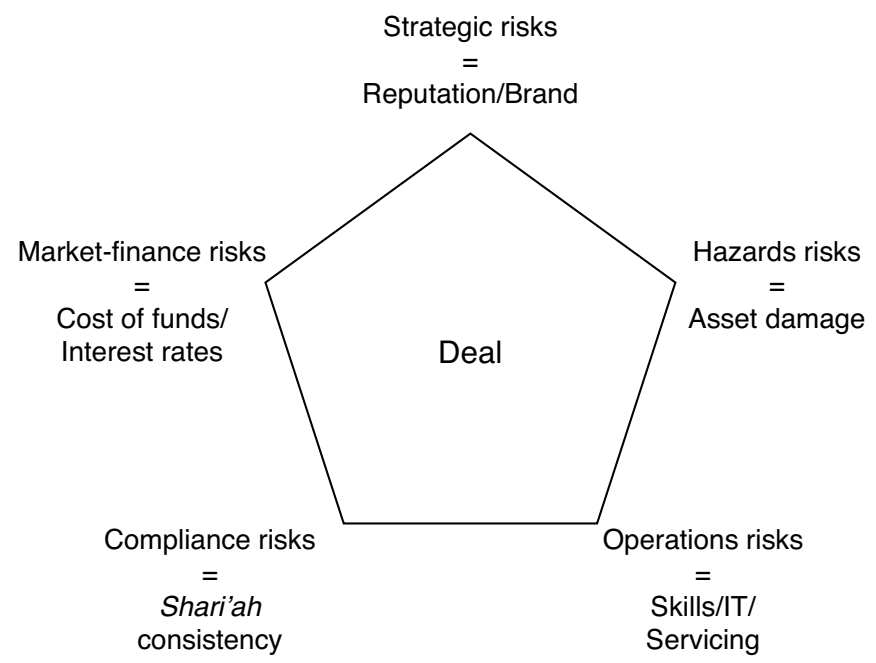

Figure 1.3 Risks of asset financing 
1. Takaful can participate in the risk of financing assets by covering certain risk elements;

2. a bank or a financial company can "cross-sell" Takaful products, something which can generate an attractive supplemental fee income.

Risk mitigation is the key to unlock higher yields from financing customers' assets. In this case a Takaful operator can be a banker's "best friend" by permitting transfer to the Takaful of unexpected losses from financial hazards and market risks of certain types affecting a borrower's default status. In addition, when a bank derives extra income from fees by acting as a broker/agent for Takaful products then such income can be added directly to improve its bottom line profits.

\subsubsection{Takaful Responses to Certain Types of Financing Risks}

There are five key areas of risk that impact asset financing. Each of these is presented in Table 1.3 in order to demonstrate in what way a Takaful cover might help a bank or financial company to extend asset financing to a potential customer.

It is clear that the risk level increases over time across each of the five areas described. Thus, banks and financial companies need to take into account risk-sharing tools such as the Takaful coverage.

The prime benefits of using Takaful coverage in order to complement an Islamic asset-financing package are the following:

- reduction in risk levels making cash flow calculations more predictable;

- improvement of an enterprise's capacity to absorb losses, which may occur due to the transfer of certain risks to a Takaful operator.

\subsubsection{A Practical Example of Takaful Coverage}

The use of two examples from Bank Aljazira's range of Corporate/ Group Takaful products may help to clarify how the above scheme may work.

The first illustration derives from an Auto Financing portfolio of SR 10.0 million, which has on average a 3 percent default rate (equal to SR 300000 annually) and an average profit margin of 12 percent. Application of Bank Aljazira's Loan Repayment Guaranty plan on the financing portfolio might result in an annual premium of SR 100000 . There is a modest reimbursement fee income to the financier of SR 50000 for performing some customer record-keeping, so the net premium costs 
Table 1.3 Takaful response to the five key areas of risk

\begin{tabular}{|c|c|}
\hline Areas of risk & Takaful response \\
\hline \multicolumn{2}{|l|}{ Strategic risks } \\
\hline - Reputation & $\begin{array}{l}\text { - Association with innovation in Islamic } \\
\text { services }\end{array}$ \\
\hline - Investor Support & - None \\
\hline - Brand Name Position & - None \\
\hline $\begin{array}{l}\text { - Customer Support/Access/ } \\
\text { Convenience }\end{array}$ & $\begin{array}{l}\text { - Customer identifies with Islamic } \\
\text { finance, ownership and builds loyalty }\end{array}$ \\
\hline \multicolumn{2}{|l|}{ Hazard-asset risks } \\
\hline - Physical Damage & - Property - General Takaful \\
\hline - Liabilities/Casualty & - Liability - General Takaful \\
\hline - Business Interruption & - None \\
\hline - Asset Quality- Residual Value Risk & $\begin{array}{l}\text { - None [could design a "put" option as } \\
\text { residual value insurance] }\end{array}$ \\
\hline -Term - Useful Life & - None \\
\hline \multicolumn{2}{|l|}{ Financing/market risks } \\
\hline - Interest Rates - Cost of Funds & - None \\
\hline - FX-Currency Risk & - None \\
\hline - Credit Quality - Payment Risk & $\begin{array}{l}\text { - Loan Repayment Guaranty Takaful } \\
\text { cover }\end{array}$ \\
\hline - Risk-Reward Ratio (ROI) & - None \\
\hline - Political Risks & $\begin{array}{l}\text { - IDB Takaful cover for Commodity } \\
\text { trading }\end{array}$ \\
\hline $\begin{array}{l}\text { - Penalties for Default Operations } \\
\text { Risks }\end{array}$ & - None \\
\hline \multicolumn{2}{|l|}{ Operations risks } \\
\hline $\begin{array}{l}\text { - Performance Risks - Unwinding } \\
\text { the deal }\end{array}$ & - None \\
\hline - Security Risk/ Collateral & $\begin{array}{l}\text { - Loan Repayment Guaranty Takaful } \\
\text { Cover }\end{array}$ \\
\hline - Ownership Risk - Perfection of title & - None [could design Title insurance] \\
\hline - Servicing Risk - timely Repayments & - None \\
\hline - Employee Skills & - Keyman Takaful cover \\
\hline - Employee Retention & - Group Retirement/Pension Takaful Plan \\
\hline - Employee Productivity & - Group Retirement/Pension Takaful Plan \\
\hline \multicolumn{2}{|l|}{ Compliance risks } \\
\hline $\begin{array}{l}\text { - Overall Shari'ah compliance with } \\
\text { Holy Qur'an and Sunnah }\end{array}$ & - Takaful is Shari'ah approved \\
\hline - Choice of Contract & $\begin{array}{l}\text { - Takaful fully compatible with Islamic } \\
\text { Financing [Bank Aljazira uses Al } \\
\text { Wakala Contract] }\end{array}$ \\
\hline - Source of Funds & - None \\
\hline
\end{tabular}


are SR 50000 annually. The net profit would be SR 900000 annually, or a 9 percent yield.

Under the Loan Repayment Guaranty coverage, any eligible claim relating to a defaulted borrower would be paid by the Takaful operator so that the remaining balance of the liability is fully repaid to the financier. Assuming that defaults were reduced by 50 percent, the ROI improves for the financier by 11 percent, from SR 900000 to SR 1000000 . Assuming that the defaults were reduced only by 35 percent, the ROI improves by 6.1 percent, from SR 900000 to SR 955000 . The advantages to the financier of such an arrangement are:

- ROI increases from - 6 percent to 11 percent;

- defaults are reduced by 35 percent to 50 percent; $; 9$

- marketing and advertising benefit to customers from Takaful cover;

- additional source of fee income;

- minimization in costs and problems of repossessing defaulted assets.

The second example involves asset financing to an individual company that has provided a personal guaranty in support of the credit-financing package. How will the financier respond if this "key" person dies or becomes disabled and his family refuse to repay the outstanding obligation? By application of Takaful Ta'awuni "key-man" coverage, which offers risk protection to the sole proprietor in the amount of the outstanding liability as it is amortized. The financier can improve his safety levels, reduce the default ratio and improve the overall profitability of the financing portfolio. In the event of the death or disability of the "key" individual, the Takaful operator immediately repays the remainder of the obligation (both principal and profit if desired) to the financier without any legal entanglements. Thus the financier benefits from avoiding costly or delayed collections and the unpleasant task of seeking money from a grieving family.

\subsection{THE NATURE OF INSURANCE PRACTICES IN ISLAMIC ECONOMIES}

Islamic insurance differs from conventional insurance since it must operate based on the concept of al-Mudharabah, a profit-sharing scheme. In addition, it must be free from elements that are prohibited by Shari'ah. In this respect scholars who are not in favor of permitting insurance practices in Islam must have based their opinions and judgments on conventional insurance practices, which certainly involve a few unlawful elements in the eyes of Shari'ah. 
Thus, here a model for Islamic insurance policy and practices is proposed, which is different from the conventional one.

1. An insurance contract binds the insurer only on a unilateral basis. The insurer is under an obligation to provide compensation against a loss to the subject matter of the policy. At the same time the insured is not forced, if he is not willing, to continue the payment of premiums. Nevertheless, it is necessary for the insured to continue the payment of premiums in order to claim benefit from the policy. If the insured discontinues the payments of premiums for some reason, the paid premium should not be forfeited.

2. The Islamic model of insurance policies is based on the fundamental principle of mutual cooperation and solidarity, as ordained by Allah $(s w t)$. Allah (swt) stated to this effect:

$$
\text { ( وتعاونو ا على البر و الثقوى ) }
$$

"Sustain a mutual cooperation among yourselves in the righteousness and piety." 40

3. A Shari'ah-based insurance policy should not involve the unlawful element of usury (Riba), but it is based on the profit-sharing financing technique of al-Mudharabah. Using this technique, the insured pays the premiums to the insurer (insurance company) who will run the insurance business with the cumulated money. The profits arising from such a transaction will be shared between the insurer and the insured accordingly. 41

4. In the case of a life insurance policy, some scholars argue that such practice is prohibited in Islam, relying on the assumption that the insurer and the insured, in this case, are trying to determine one's life or death (Muslim Brotherhood, 194142). However, such criticism is proven to be groundless.

5. In an Islamic model of life insurance, however, the nominee is not an absolute beneficiary. Instead they are a mere trustee who is under an obligation to receive the benefits from the policy and to distribute them among the legal heirs of the deceased. This action is taken in accordance with the principles of "Mirath" and "Wasiyah". 43

6. In a regular insurance transaction, the agent is employed by the insurance company. Hence, it is suggested that the agent should also have a certain share in profits from the business carried out by the insurance company in the form of a salary. The agent therefore should not be paid out of the insurance premiums.

7. In life insurance, if the insured passes away at any time before the maturity of the contract period, the beneficiary is expected to claim 
the total paid premiums, the share of the profit and possible dividends made from the paid premiums. All of the above are based on alMudharabah financing technique plus an additional sum in the form of a donation from the company. This sum of money is taken out of the company's charitable fund upon considering the financial status of the beneficiaries. ${ }^{44}$ But if the insured person is alive upon the maturity of the period of the insurance contract, then the insured is entitled to claim from the insurer the total paid premiums as well as the share of the possible profits and dividends accordingly.

8. In the case of general insurance, it has to be mutually understood by the insurer and the insured that the insured's premium payments will be given out as a donation, based on the principle of "Tabarru" 45 (donation or contribution). In such a case the insured cannot legally claim back the premium, if there is no loss regarding the agreed subject matter. However, if a loss or damage occurs to the subject matter within the policy period, the insurer is unilaterally bound to pay the agreed compensation to the insured for that particular loss or damage.

9. The person who claims the benefits from an insurance policy must have an insurable interest in the subject matter.

10. The parties involved in an insurance policy must have legal capacity to enter into an insurance contract.

\subsubsection{The Nature of an Islamic Insurance Contract}

Generally, the scope of an Islamic insurance policy is very wide and flexible. Such wide scope and flexibility are just in order to ensure a smooth life for the members of the society, which is in line with the following sanction:

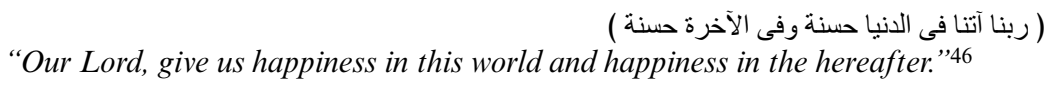

In spite of the wide scope and flexibility of the Islamic insurance policy, there are certain limitations set by the Shari'ah in order to purify the insurance transactions. For instance, Allah (swt) prohibited any kind of accumulation of profits and wealth by way of unjust enrichment. He commanded to this effect:

$$
\text { ( لا تأكلو ا أمو الكم بينكم بالباطل إلا أن تكون تجارة عن تر اض منكم ) }
$$

"Do not eat up your property among yourselves in vanities, but there be amongst traffic and business by mutual goodwill." 47 
Analytically, the limitations imposed by the Shari'ah to an insurance policy are as follows:

1. A contract of insurance should not involve an element of "Riba" in its investment activities or any other activities ${ }^{48}$ undertaken by the insurance company. This is because, besides its being totally forbidden in Islam, it creates, inter alia, the sense of selfishness, miserliness, greed and malevolence, at the individual level. Therefore, Haji Azlan Khalil accepts the view of M.V. Khan that the institution of "Riba" could lead to a miserable, unstable society. ${ }^{49}$ Allah (swt) warns the believers against involving "Riba" in their transactions. He (swt) says to the effect:

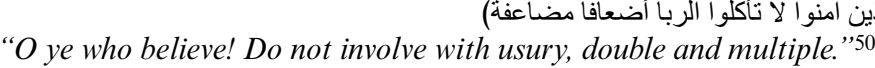

$$
\text { ( با أيها الذين آمنو الا تأكلو ا الربا أضعافا مضاعفة) }
$$

2. Thus, an Islamic insurance business should be based on the principle of the al-Mudharabah financing technique as an alternative to the principle of fixed-rate interest. ${ }^{51}$

3. The nominee in a life insurance policy is not an absolute beneficiary as is the case under the conventional insurance system. ${ }^{52}$ Such a nominee is only a mere trustee whose obligation it is to receive the benefits from the policy and distribute them among the legal heirs of the deceased (insured) $)^{53}$ in accordance with the principles of "al-Mirath" and "alWasiyah". 54 This responsibility is shouldered by the nominee and is just to enable the heirs of the insured to enjoy a fair distribution of the benefits of the policy.

4. An insurance contract is only enforceable if it does not contradict any of the principles of Shari'ah. This has been clarified by the Malaysian Takaful Act 1984: "Takaful business means a business of Takaful whose aims and operations do not involve any element which is not approved by the Shari'ah." 55

5. Every individual in society has the freedom to buy an insurance policy. The only exceptions to this general rule are set out as follows:

- Any person under the age of eighteen. The Malaysian Takaful Act states: "A person under the age of eighteen years shall not have the capacity to enter into a contract of Takaful." 56

- A person who is in a state of having an unbalanced mind and/or who is ill (medically incapacitated) is also prohibited from entering into a contract of insurance.

6. An insurance contract does not aim to make a profit as it is a mutual transaction aimed at fostering the sense of mutual cooperation among the parties to the contract in order to establish brotherhood and solidarity among them. Thus, in an insurance policy, there is 
mutual cooperation between the involved parties whereby the insured undertakes to pay the premiums throughout the period of the policy. On the other hand the insurer undertakes, in return, to provide the insured with the necessary material protection against an unexpected risk, danger or loss. Allah (swt), in the Holy Qur'an, has enjoined such mutual cooperation to be established among people. He (swt) says to this effect:

$$
\text { (وتعاونو ا على البر والتقوى ) (And cooperate one another in righteousness and piety." }
$$

7. If either party to the insurance contract has the intention of profiting from the contract instead of establishing mutual cooperation, the transaction will become morally and spiritually unlawful. Hence, the involved parties of the contract are also required to impart purity and sincerity in their hearts in order to abide by the principle of mutual cooperation as enjoined by the Holy Qur'an.

8. The fundamental aspects of insurance must be controlled and supervised by the State Authority based on the Shari'ah rules and nothing should be left unchecked. Such a wise policy is aimed at ensuring the legality and fairness of all transactions conducted by the insurance companies. This is because insurance businesses are considered as "Amanah" or trusts, where the insurance companies undertake to protect the insured from future unexpected losses, damages, risks or perils.

Nejatullah Siddiqi (an Indian economist and winner of the King Faisal international prize for Islamic studies), suggested to this effect:

"All insurance concerning perils to lives, limbs, and health should be dealt with exclusively under the supervision of the state." 58

He further suggested:

"Insurance against peril involving money and property should also be run by the state." 59

Again, he clearly states in his proposal that all kinds of insurance practices should be dealt with under the supervision of the State Authority.

\subsection{AN EMPIRICAL PARADIGM OF TAKAFUL EXPLAINED}

The nature of the basic principles of Takaful is fundamentally different from the nature of the principles of conventional insurance. However, 
an attempt is made in this section to analyze the conceptual framework of Takaful practices in the modern economic environment and to offer possible recommendations for the improvement of Takaful. It is hoped that the suggestions made above for further development of Takaful may contribute to the future standing of Takaful both in principle and practice. Furthermore, that it may meet the Ummah's expectation of benefiting from the application of Islamic insurance in a wider range, without further depending on the insurance practices operated under the banner of the conventional economy.

\subsubsection{Conceptual Framework}

The concept of insurance (Takaful), according to Islamic Finance Scholars, is acceptable in Islam for the following reasons:

- The policyholders cooperate ${ }^{60}$ with each other for their common good.

- Every policyholder pays a subscription in order to assist those of their group who need assistance.

- It falls under the donation contract which is intended to divide losses and spread liabilities according to a community pooling system.

- The element of risk is reduced.

- It does not aim at deriving financial advantage at the cost of other society members.

Under Islamic Financial Law, in general, any financial transaction that has the elements of unjustified profitability, uncertainty and unidentified risks, or Riba, would be a reason to cancel an insurance contract. ${ }^{61}$ Clearly, an insurance contract under Islamic Law would not be valid unless it were free from the above prohibited elements.

The nature of the principles of Takaful is fundamentally different from the principles of conventional insurance. The differences are as follows: First of all, the operations of Takaful must be in line with the Shariah principles. ${ }^{62}$ A Takaful operation may be held void ab initio if any aspect of its operation is proven to be contrary to the Shari'ah principles. Second, the operation of Takaful is generally based on the governing principles of alMudharabah, which is a profit and loss sharing financing technique. ${ }^{63}$ This technique is an alternative to the interest ( $R i b a$ )-based financing technique as adopted by the conventional insurance practices. Third, the operation of Takaful practices is generally supervised by an independent body called the Shariah Supervisory Council. ${ }^{64}$ It is the duty of the Council to advise 
the Takaful operator(s) with the purpose of ensuring that no company's operations involve elements that are not approved by the Shari'ah Law. In other words, the establishment of a Shari'ah Supervisory Council for every individual Takaful operator is a prerequisite prior to the commencement of the Takaful operation.

It is also within the fundamental principles of Takaful operation to maintain good faith in Takaful operations. This is because if a Takaful policy is called into question, either party (operator or participant) should be able to prove their good faith in the material matters or facts of the contract. Therefore, the duty to disclose information is not imposed only on the operator but on all participants equally.

\subsubsection{Analysis of the Principles of Takaful}

It has been observed that the principles and practices of Takaful are still at an initial stage but in some countries it has made significant progress. Despite the developments in the field of Takaful, there is still room for improvement and necessary changes are needed in order to make Takaful more attractive and beneficial to the Islamic world now as well as in the future.

1. In Takaful there is no room for cheating, and the policy, as well as the benefits of the policy, are regarded as the legitimate wealth of the policyholder. Hence, there should be a legitimate relationship between the involved parties, whereby the beneficiaries are not prohibited from claiming the potential benefits of the policy. Such a relationship is referred to as an insurable interest. It is one of the fundamental aspects in insurance practices and under Islamic Law can only be determined based on the principles of Mirath and Wasiyah. The person who will be the beneficiary of the contract is determined based on the principles of Faraid. ${ }^{65}$ The insurance policy will not be valid unless there is an insurable interest between the insurance policy buyer and the proposed beneficiary. This is because having an insurance policy without ensuring an insurable interest is like a policy for gain, which violates Shari'ah principles.

2. An insurance policy is a financial transaction that binds both the operator and the participant based on the general principles of al-'Aqd (contract). The minimum acceptable age of a contract under Islamic Law has been set by Islamic Scholars who have unanimously agreed that it should be the age of Rushd (puberty or majority). ${ }^{66}$ However, there are different views amongst Islamic Scholars in setting the exact age of Rushd. 
3. It is widely recognized that agents and brokers in the field of insurance practices are the ones who contribute, inter alia, to the development of insurance practices in commercial societies at large. Unfortunately, this is not the case regarding the practice of Takaful. The main reason for this is the lack of publicity about the concept, significance and social importance of Takaful practices. It is believed that the insurance agent and the brokers could be used in the development of Takaful operations in order to make it more popular and to make the Muslim world realize its significant importance.

Now as far as the practices of Takaful are concerned we can make the following comments.

- Theoretically, in the case of general Takaful, participants are required to pay contributions, al-Tabarru' (donation or charity). However, in practice, the Takaful operator and participant in the general Takaful case mutually agree that in consideration of the paid contributions, the Takaful operator will undertake the responsibility of providing a pecuniary insurance coverage for the participant against risks within the policy period.

According to Islamic principles of al-Tabarru', which is like and has similar legal consequences to al-Sadaqah (charity), al-Hiba (gift) and al-Khairat (donation), anything once given as a donation in favor of something or someone, cannot generally be taken back. The donor automatically loses property title over the donated item as soon as it is made as al-Tabarru', al-Sadaqah, al-Hiba or al-Khairat.

The comment here is that, if the paid contributions in the general Takaful are regarded as al-Tabarru', according to Islamic Law the contributions cannot be reclaimed as they have been given away as Tabarru'. In practice, however, the participant continues to hold a right of claim in consideration of the paid contribution against the risk on the subject matter. Therefore, it is not clearly understood what provision can justify paid contributions being regarded as alTabarru' in a general Takaful.

- Non-Muslims may be allowed to buy a policy from a Takaful operator but it does not mean that the Takaful operator should adopt something in favor of the non-Muslim participants that may be in contrast to the main nature of a Takaful operation. The operations of the Takaful sold to Muslims or non-Muslims must be in total compliance with Shariah sanctions. In the case of a family Takaful, it is true that, if the policyholder is a non-Muslim who nominates someone, the nominee is to be regarded as an absolute beneficiary. ${ }^{67}$ 
In such a policy where the nominee is regarded as an absolute beneficiary, this may be in contrast not only with the Islamic Law of Faraid, but also with the law of inheritance. Moreover, allowing a non-Muslim policyholder to regard a nominee as an absolute beneficiary may also encourage the non-Muslims to hope for a gain in favor of the nominee without regarding others who may be affected by the possible death of the participant. Therefore, such an opportunity for the nominee to gain is contrary to the main objective of Takaful operation, which is to maintain the notions of brotherhood, solidarity and mutual cooperation.

- With regard to the life expectancy of any person, no live creature can determine one's life expectancy based on imagination or unfounded prediction. In certain cases on the determination of life expectancy, it has been observed that Takaful operators use probability theory. By doing so, they impose charges at lower rates and give higher annuity rates for females than males. Such gender discrimination in the imposition of charges and the provision of annuity rates is based on the statistical fact that the death probability of females is generally lower compared with the death probability of males. Such discrimination by the Takaful operator creates a doubt as to whether or not it could be justified by the Shari'ah principles. The life expectancy of human beings is determined only by Allah ( $s w t$ ) regardless of the gender of the creature and, therefore, no creature should overrule the power of Allah (swt). Furthermore, it is true that sometimes females may die before males. Therefore, it is groundless to make gender sex discrimination on one's life expectancy.

- In the practice of Retakaful coverage two systems are available: the treaty system and the facultative system. The coverage through the facultative system is performed by using two categories of reinsurance companies: a local re-insurance company, which operates based on conventional principles, while the other coverage is based on Shari'ah principles. The coverage based on the treaty system operates with the aid of brokers at the international level at which the brokers take the policy from both conventional and also Islamic re-insurance companies.

The question that arises here is the justification of the Islamic companies in seeking coverage from re-insurance companies that operate based on the conventional principle. It is argued that these practices may create an obvious opposition with the objectives of Takaful operations. Moreover, having a mutual cooperation between the Islamic and non-Islamic insurance companies may be regarded 
as a mixture of truth and falsehood, which has no place in the fundamental teachings of Islam as enshrined in the Holy Qur'an:

"And cover not truth with falsehood, no conceal the truth when you know (what it is)." 68

\subsubsection{Possible Recommendations for the Paradigm}

As previously mentioned, despite the developments in the operations of Takaful, there are still some aspects of Takaful, both in principle and in practice, which need to be developed further in order to make the Takaful operation an alternative to the conventional insurance schemes. Here we seek to come up with some possible suggestions, which may contribute to the further development of the principles and practices of Takaful in the modern Muslim world.

1. The objective of the governing principles of insurable interest is to make the policy and its benefits crystal clear, while ensuring that such a policy should not be used as a tool to cheat and profit. Therefore, conformity to the principles of insurable interest in an insurance policy is one of the fundamental aspects. In relation to this, we must repeat that the general principles of insurable interest should be based on the principles of Faraid, ${ }^{69}$ in which the benefits from the policy should be regarded as the asset of the participant. Further, insurable interest can only be vested in those who, according to the general principles of Faraid, have beneficial rights over the estate of the participant after his death.

2. Even though an insurance transaction is generally based on the principles of al-'Aqd (contract), the nature of this transaction is quite different from other forms of commercial contracts. This is because an insurance policy is for the purpose of sharing responsibility in order to provide some material security against unpredicted loss or damage resulting from unexpected risks for both life and property.

3. The agent and the broker in the insurance policy play an important role as the promoters of insurance practices among society's members. In order to make Takaful operations popular in their societies and to attract people to the practices of Takaful, it is suggested that Takaful operators should be licenced agents and brokers who may work specifically for the development of Takaful operations.

4. In order to have a reliable authority relating to the principles of Takaful operations, it is suggested that statutory provisions should contain an express provision relating to the principles of Takaful operations, for example an al-Mudharabah financing technique, so 
that there should be no doubt as to whether Takaful operations are based on al-Mudharabah financing.

5. Al-Tabarru' has a similar nature and also similar legal consequences to the terms of al-Sadaqah, al-Hiba and al-Khairat, which all generally carry the meaning of donation. Furthermore, in accordance with Islamic Law, the donor automatically ceases to have a right to the donated property once it is made as al-Tabarru' in favor of someone or something. Then, if the paid contribution in the general policy is regarded as al-Tabarru' (in consideration of which the participant holds a right to claim the coverage against the risk on the subject matter of the policy from the operator), this may contrast with the fundamental principles of the Islamic Law of charity.

It is therefore suggested that the paid contribution in the general Takaful may be regarded as al-Musahamah (contribution) instead of al-Tabarru' (donation). This is because if the paid contribution in the general Takaful is regarded as al-Musahamah (contribution), the participant has no restriction in Islamic Law to make a claim against the risk on the subject matter of the policy. It is again strongly believed that there is no provision in the Shari'ah which may prohibit the contributor from making a claim or seeking a benefit over his own contributed fund. The establishment of such a contributed fund can also be justified by the Qur'anic sanction of mutual cooperation:

"Help you another in righteousness and piety."70

6. With regard to the nomination in a family Takaful nominated by a non-Muslim policyholder, the current practice of Takaful operators is that the nominee nominated by a non-Muslim policyholder should be treated as an absolute beneficiary ${ }^{71}$ of the benefits of the policy. Nevertheless, this practice may be contrary to Shari'ah principles. Being a non-Muslim, the policyholder cannot be allowed to treat the nominee as an absolute beneficiary. Furthermore, it is strongly believed that if the nominee is treated as a mere trustee of the policy he may distribute the benefits among the heirs of the policyholder. This may make a fair judgment to the right beneficiary. Therefore, it is suggested here that since Takaful is a Shari'ah-based financial service it should not be subject to laws and faiths that may be in contrast to Shari'ah principles. Thus, the nominee in the family Takaful, regardless of the religion of the policyholder, should be treated as a mere trustee or executor (but not an absolute beneficiary). In addition, it should be his responsibility to receive the benefits from the policy and distribute them among the right beneficiary(s) in accordance with the principles of their respective religion or faith. 
The reason for this is, if the Takaful operator should allow himself to adopt certain elements (like treating the nominee nominated by the non-Muslim policyholder as an absolute beneficiary), this may be contrary to Shari'ah principles. Also, such actions can be considered as believing particular aspects of Shari'ah principles while neglecting the rest of them. This has no place in the Shari'ah teachings.

7. With respect to gender discrimination in a financial transaction, it is clear that it is groundless for the Takaful operator to assess life expectancy and discriminate between males and females through imposing or giving higher or lower rates. Therefore, it is suggested that the Takaful operator should impose and give reasonable rates of charges to the participant regardless of their gender.

8. As far as Retakaful is concerned, the Takaful operator should not obtain coverage from the conventional re-operators as this practice is contrary to Shari'ah principles. The Holy Qur'an expressly provides that Muslim should not cooperate with nor should they seek help from non-believers.

Allah (swt) commanded:

"Let not the believers take for friends or helpers unbelievers rather than believers, if any do that, in nothing will there be help from Allah (swt), except by way of precaution, that you may guard yourself from them. But Allah (swt) cautions you (to remember) himself for the final goal is to Allah (swt)." "72

Therefore, in view of the above, Takaful operators may seek Retakaful coverage only from other Takaful companies that operate based on Shari'ah principles. For the purpose of seeking a further comprehensive Retakaful coverage, Muslim countries of the modern world should come forward to establish necessary re-insurance companies both at local and international levels justified by the principles of Shari'ah. So far, five re-insurance companies have already been established and are operating based on Islamic principles. Examples are: The ASEAN Takaful Group (ATG) (Malaysia); Asean Re-Takaful International (L) Ltd (Malaysia); IIR Co. (Bahrain); Islamic Re-Takaful Ltd (Bahamas); and BEST RE (Middle East). This may enable the Islamic insurance companies of today to seek re-insurance coverage through both facultative and treaty systems without further depending on conventional re-insurance schemes. 


\subsection{THE BASIC ELEMENTS OF TAKAFUL EXPLAINED}

Insurance practices generally became established in the 14th century. During that time, interest was stronger when economists attributed a number of socio-economic advantages to insurance practices. In the teachings of Islam, to be lawful, any practice should conform with Islamic Shari'ah. The 'Aqd of insurance is something relatively new, and had not been used in the context of Islamic Shari'ah until the beginning of the 19th century. However, any Aqd originally is not lawful unless it is proved it is against the principles of Islamic Shari'ah. Ibn Abidin was the first scholar who dealt with judging insurance practices in the early 19th century and thereafter many Fatawas and arguments for or against insurance practices have been developed. Most of the arguments are based on Qias to other Islamic 'Uqud such as Aqilah, Mualat, Kafala and alWa'adulMulzim.

The following section will discuss Islamic contracts ('Uqud) that justify the contract ('Aqd) of insurance.

\section{القسامة (al-Qasamah) - Oath/Swear}

In the light of Islamic jurisprudence, the term al-Qasamah means an oath taken by 50 members of a tribe or a locality to refute accusations of homicide. Imam Malik Bin Anas $(R A)$ ruled to this effect:

$$
\begin{aligned}
& \text { فيحلف منهم خمسون رجلا خمسين يمينا فإن لم يبلغو ا خمسين }
\end{aligned}
$$

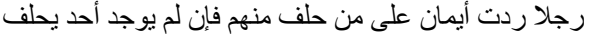

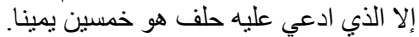

"So fifty of the men of his people swear fifty oaths. If there are not fifty men, more oaths can be made by those of them who already swore. If there is only the defendant, he swears fifty oaths and is acquitted." 73

For instance, if a dead person is found in a certain place with signs of violent death, the legal heirs of the possible victim are entitled to call upon 50 residents of the place whom they may select to take the oath that none of them killed the dead person. If they take that oath, then all residents have to pay al-Diyah (blood money), otherwise they have to serve a term of imprisonment. Similarly, if a dead person is found at the door of a man's house, he shall also be given the oath and, if he swears that he did not kill that person, his Aqilah (paternal relatives) shall share the payment of the blood money. All schools of Islamic jurisprudence recognize the doctrine of al-Qasamah. As far as the Medinan society was concerned, the doctrine of al-Qasamah was used as a way of imposing a penalty against 
the offence of homicide where the guilt of the accused person could not be established by any manner. According to Maliki, a statement by a dying person charging the accused with his death or one eyewitness of a killing is sufficient evidence to establish the offence. Nevertheless, the School of Shafii (RA) disagreed with Malik's point of view as Maliki included the naming of the killer by the dying victim as a reason for suspicion, something which the Shafii did not admit, and excluded the proof of existing enmity between the accused and the victim, something which Shafii admitted. The Hanafi School, on the other hand, took no part in this dispute, but preserved the particular tradition of the School of Kufa, under which al-Qasamah is an essentially defensive procedure, that is, 50 oaths being taken by the residents of the neighborhood in which a dead body had been discovered to dismiss the charge that a member of the local community had committed the homicide. ${ }^{74}$

However, under the doctrine of al-Qasamah, it appears that the payment of blood money had been shared by the members of the community towards providing financial security to the legal heirs of the deceased. Takaful as we practice it today in fact has a basis in al-Qasamah as all the participants in a Takaful scheme contribute to a fund towards providing financial security for someone against a well-defined risk or damage.

\section{الفدية (al-Fidyah) - Ransom}

Fidyah is a consideration paid by the spouse, family, tribe or a friend to free a prisoner from the hands of enemies. Fidyah was in practice in Arab societies before the time of the Prophet (saw).

In the Battle of Badar, Muslims kept the Qureshi captive for ransom, apart from two captives who were executed for their notorious activities against Muslims. The ransom of each of the prisoners varied in accordance with his financial status. Some of the captives paid the ransom money and some of them were assigned ten children to teach until the children became proficient in reading and writing. Other captives who could not afford to pay the ransom or who were unable to teach were set free without any compensation. ${ }^{75}$

Allah (swt) says in the Holy Qur'an:

$$
\text { (فإذالقيتم اللذين كفروا فضرب الرقاب الرقاب حتى إذا أنخنتموهم فثدوا الوثاق فإما مناً بعد وإما فداء حتى }
$$

"Therefore, when ye meet the Unbelievers (in fight), smite at their necks; at length, when ye have thoroughly subdued them, bind a bond firmly (on them): thereafter (is the time for) either generosity or ransom: until the war lays down its burdens." 76 


\section{(Istijarah) - Asylum}

Istijarah (asylum) is a shelter given to a helpless person who has no one to protect them. Istijarah was a common practice in Arab societies. There are occasions when Rasulullah (saw) and his companions were provided asylum by the Qurishian against the notorious individuals from the Kufar in Mecca. For instance, Rasulullah (saw) went to Taif to invite the people of Taif to Islam. Zaid, his freed slave, was in his team on the journey to Taif. On his way back from Taif to Mecca, he sent Zaid to seek asylum for him among his friends in Mecca. MutimIbnAdi provided asylum for him (saw) and then he returned to Mecca.

In the Qur'an, Allah (swt) ordered the Prophet (saw) to give asylum to the Mushrikin so as to enable them to listen to the words of Allah (swt):

( و إنأحد من المشركين استجارك فأجره حنى يسمع كلام الله ثم أبلغه مأمنه ذللك بأنهم قوم لا يعلمون ) "If one amongst the Pagans ask thee for asylum, grant it to him, so that he may hear the word of Allah (swt); and then escort him to where he can be secure. That is because they are men without knowledge."77

Rasulullah (saw) also in the event of Fatih Mecca considered the asylum provided by Amu Hani.

\section{(al Hilf) - Allies}

Hilf literally means deal and oath to support each other. Ibnu al-Asir said the origin of Hilf is an agreement to support each other. ${ }^{78}$ In Arabia, the agreement of Hilf used to take place between an individual and a tribe; between an individual and another individual; between a tribe and another tribe; or among a group of people. Among the well-known Hilf in the time of Jahilyah were Hilf al-Mutaibin, al-Ahlaf and HilfalFidul. ${ }^{79}$

\section{(Hilf al-Mutaibin) - Allies of al-Mutaibin}

Hilf al-Mutaibin (the allies of al-Mutaibin) was a Hilf among tribes. IbniIshak said those tribes were Abdu Munaf, Asd, Zuhrah and Tmim, the people of Abu Bakar (RA).

\section{(Hilf al-Ahlaf) - Allies of al-Ahlaf}

Hilf al-Ahlaf (the allies of Ahlaf) was among the tribes of Gamah, Saham, Makhzum, and Adi, the people of $\operatorname{Umar}(R A)$. 


\section{(Hilfu al-Fidul) - Allies of al-Fidul}

Hilfu al-Fidul was among a group of people twenty years before the revelation of Islam. Rasulullah (saw) himself and his companion Saidina Abubakar participated in this Hilf. The Hilf took place as a response to a public appeal made by a Yemeni merchant who was defrauded by a Qurish merchant. AbdAllah (swt) IbnJudan, the chief of the tribe of Taym, called for the pact and accordingly the Hilf was formed. Later, Rasulullah (saw) said:

"I was present in the house of Abdullah IbnJadan at so excellent a pact that I would not exchange my part in it for a herd of red camels and if now in Islam I were summoned unto it I would gladly respond." 80

Hilf was practiced by Rasulullah (saw) after the revelation of the Qur'an. He had established Hilf between the Muhajerin and Ansar and Muslims in Madinah and some tribes of the Arabs.

Examples and differences among the Fuqaha on the Naskh of Hilf are outlined below.

\section{الموالاة (al-Mualat) - Contract of Clientage}

In the School of Hanafi, Mualat means a contract between a man who has no next of kin and a man who has next of kin. In this scheme, any liability against the first is to be borne by the second's relatives and the second inherits the whole property of the first. ${ }^{81}$

In the School of Ja'fari, Mualat means a contract between two men with no next of kin. Accordingly, they inherit each other's property and bear one another's liability. ${ }^{82}$

Al-Mawla (the person who is involved in the contract of al-Mualat) means: ${ }^{83}$ al-Nasir (supporter), al-Sharik (partner), al-Halif (alliance):

"That is because Allah (swt) is the protector of those who believe, but those who reject Allah (swt) have no protector." 84

\section{العاقّة (al-’Aqilah) - Kinsmen (Payee of Blood Money)}

In the Arab tradition, Aqilah refers to the payee of blood money. Aqalun is the Masdar of Aqala, which means to tie or prevent. The word Aqalun was used to mean blood money. This is because when a tribe of a killer brought camels as settlement of the blood money they used to tie them up in a road of the killed person's tribe. It also said that the word Aqalun 
refers to blood money because the tribe of the killer supports him by paying blood money. ${ }^{85}$

In Fiqh (Islamic jurisdiction), the word Aqilah refers to a group of people who have to pay 'Aqalun (blood money) in accordance with Shari'ah Law.

The doctrine of Aqilah is based on the tradition of the Prophet (saw): ${ }^{86}$

"Narrated by Abu Hurairah (RA), who said that: once two women from the tribe of Huzail clashed when one of them hit the other with a stone, which killed her and also the foetus in the victim's womb. The heirs of the victim brought an action to the court of the Holy Prophet (saw), who gave a verdict that the compensation for the infanticide is freeing of a male or female slave while the compensation for the killing the woman is the blood money (Diyah), which to be paid by the 'Aqilah' (the paternal relatives) of the accused." 87

Fuqaha unanimously agree that blood money of unintentional killing is claimed from the Aqilah. However, there is a difference in the specification of Aqilah. ${ }^{88}$ The majority of Fuqaha supported the opinion that Aqilah refers to male relatives of the killer but not ascendants and descendants of the killer. In other words, it refers to the killer's brothers and their sons and uncles and their sons. ${ }^{89}$

The Hanafi School follows the opinion that Aqilah refers to persons who are obliged to assist one another. This was an outcome of the new social order that Muslims experienced. The social life changed from that of the Arabs in Arabia in which people were living among their tribes before the spread of Islam. When Muslims spread throughout the world it became difficult for someone who is far away to refer to his tribe or relatives. ${ }^{90}$ The Hanafi defended their view by referring to the practice of the second Caliph, Umar $(R A)$. Umar $(R A)$ commanded that various districts should prepare a "Diwan" list of the Mujahideen. Members whose names are on that "Diwan" list owe assistance to one another and they bear one another's liability. ${ }^{91}$

Another difference among Fuqaha concerns the contribution of the author of the action to the liability arising from his action. The Shafii and Hambali Schools are of the opinion that the author of the action is not obliged to contribute any amount of money, while the Hanafi and Maliki Schools are of the opinion that the author is obliged to contribute to the payment of the blood money equally as the members of Aqilah. ${ }^{92}$ In the case where a person has no next of kin, then his Aqilah is Baitul mal (the public fund).

Rasulullah (saw) said:

"I am the Legal Heir of a person who does not have any heir and I pay blood wit to discharge him from liability and I become his Heir." 93 


\section{Barakat Abu Ishaq Ibrahimi, the Blessing of $A b u I s h a q^{94}$ and سوكرة (Sukrah) - Marine Travel Insurance}

The term Barakat Abu Ishaq refers to a Sufi order of the Karzu, which used to provide a marine travel insurance service. The order was associated with the belief in the power of the Baraka (blessing) of Abu Ishaq. It was believed that the Baraka (blessing) guaranteed safety and protection against the risk of traveling by sea.

When merchants intended to travel by sea to Malabar or China they used to sign an agreement with the order to pay a specified amount of money upon safe arrival at their destination. At the port of destination agents of the order would collect the amount agreed upon.

Sukrah is an Arabic term, which was used to mean insurance (especially marine travel insurance) in the early 19th century as mentioned by Ibn Abidin (a Hanafi Scholar). The term Sukrah was influenced by the Italian term "Siguor" and the Turkish term "Sigorta".

Sukrah (insurance) was practiced between Muslim merchants and Italian merchants, and Abdin is the first Shari'ah Scholar dealing with the 'Aqd of Sukrah. He mentioned Sukrah in Radul al Muhtar Wa Durr al-Mukhtar:

"It is not allowed for a Muslim in our land (Islamic State) to conclude a contract with the Mustamin (non-Muslim who entered the Islamic state under a pledge of peace) except those 'Uqud which are lawful among the Muslims. And it is not permissible to take from him anything, which is binding on him, although it is customary. Like what is taken from the visitors of the Aqsa Mosque." 95

"And from our noting, the question about which a large number of inquiries are being made, is also answered and it is that, when merchants charter a ship owned by the subject (s) of a belligerent state, then, together with the charges for the ship, another amount is separately paid to the same or another subject of the belligerent state. This payment is known as 'Sukrah' or insurance premium and its payment means that in case goods on the particular ship catch fire, or if the ship capsizes or if the person who received insurance premium, is responsible to indemnify the merchant(s) who incurred the loss. An agent of the person receives the insurance premium, resides in the coastal cities of our country as a protectorate, after obtaining permission from the government. He receives the premium amount on behalf of his principals and, in the case of destruction of goods, indemnifies the insured for the entire loss. "96

"To me (Ibni Abdin) it is not allowed for the Muslim Merchant to take compensation for any damage of his property. Because it is not binding under Islamic Law." 97

"If you say a depository who takes Ugrah is liable if the deposit is damaged. I say our problem here is not from this category. Because the property insured is not in 
the hands of the insurer. It is in the hands of the owner of the ship and even if the insurer is the owner of the ship then he is a partner, he took Ugrah for saving and transporting the property. Both depository and hired person cannot be held liable for something that cannot be avoided such as death, drowning and the like."98

"If you say it is like Kafalat al-Rjulin Bailment or Daman al-Khatar al-Tariq if someone says to another person: take this, it is safe, and subsequently the second person takes the route and loses his property then the first will not liable. However, otherwise if it is unsafe and you lose your property, I stand surety, then he is liable." "99

"There can be for a Muslim merchant a Harbi partner who resides in the state of infidels. The partner may conclude the contract with insurance company in the state; and he takes the compensation and sends it to the Muslim merchant. It is lawful for the Muslim merchant to take the compensation because the void contract was concluded between Harbi and Harbi in a non-Islamic state. And he (the Muslim Merchant) took their property with their consent; therefore, there is no objection to take it." 100

A Muslim merchant may reside in a non-Islamic state. Subsequently, he may conclude a Sukrah Aqd (contract) and take compensation in the Islamic state and vice versa. In the first case, there is no doubt if there is a dispute between the Muslim merchant and the agent of the foreign insurance company. In such a case the Muslim merchant cannot demand compensation.

If there is no dispute and the agent (who lives in the Islamic state under a pledge of peace) paid the compensation to the Muslim merchant, it is lawful for the Muslim merchant to take it. This is because the Aqd (contract), which was concluded in their state (infidel's state), has no Hukum. And he took his property with his consent. However, in the opposite case in which the contract is concluded in our state and receipt of compensation in their state then it is not lawful to take the compensation even with the consent of the Harbi, because it is based on a Fasid (void) contract according to the Shari'ah jurisprudence.

\section{(al-Dhaman) - Liability or Civil Liability in Broader Meaning}

Dhaman generally means liability that arises from the causing of damage or harm to others "Ta' adi" or for not performing a contract. 101

Dhaman is one of the devices adapted by Islamic Shari'ah to safeguard society by protecting people's property. Allah (swt) says in the Qur'an:

"Allah (swt) doth command you to render back your trusts to those to whom they are due."102 
Rasulullah (saw) also says in a Hadith:

من أوقف دابة في سبيل من سبل المسلمين أو في سوق من أسو اقها فأوطأت بيد أو رجل فهو ضامن "If someone left an animal in any public place (road used by Muslims or the market) untied and if it causes any damage to the property of others, he shall be liable for the damage caused by his untied animal."

Particular cases of al-Dhaman are the following:

ضمان المجهول وضمان مالا يجب (Dhaman al-Majhul and Dhaman Ma La Yajib) - Bearing Liability of Uncertainty and Bearing Liability but Not Binding

Dhaman means assurance or guarantee and it refers to a liability created by a contract. Fuqaha refers to this liability as Dhaman or Kafala respectively. According to the Hanafi, Maliki and Hambali Schools, the contract of Kafala is permissible and any liability arises from it is binding. For example, a person in the capacity of bailor (Kafil) says to someone else (MakfulLahu) that if he sells a particular item to another individual, he will guarantee the contractual price; or a bailor (Kafil) says to a creditor that he will give a loan to a debtor (al-MakfulBihi), and he will guarantee the settlement of the loan. ${ }^{103}$

\section{الكفالة (al-Kafala) - Bailment}

There is a special type of Kafala, which is known as Kafala Bijua'l.

Al-Kafala Bijua'l is a unilateral contract in which the Kafil (bailor) stands surety for compensation. For example, a person says they will give $\$ 100.00$ for a person who does something. This is similar to what is mentioned in the Qur'an in the story of Saidina Yusuf Alaihial-Salam:

"They said: 'we miss the great breaker of the king for him who produces it is (the reward of) a camel load; I will be bound by it'."104

The majority of Fuqaha allowed al-Kafala Bijua'l. According to Malikis and Hamblis this contract is permissible and binding.

\section{الوعد الملزم عند المالكية (al-Wa'du al-MulzimInda al-Malikiyah) - Binding} Promise in the School of Maliki

The principle of al- $W^{\prime} a d$ (promise) applies when al-Wayeed (the person who promises) promises another person al-Mawa'ud (the person who is promised) something such as bearing his liability, giving him a loan and so on. Fuqaha of the Maliki School disagree over whether such a thing 
is binding or not. ${ }^{105}$ Some of them say it is binding without any exception; some of them say it is not binding at all; some of them say it is binding if there is a cause for it, regardless of whether the cause has been conducted or not. For example, if a person says to another, I will give you a loan to get married, then it is binding, regardless of whether the person gets married or not. Some of them say it is binding only if the cause is conducted.

\section{ضمان على خطر الطريق (Dhaman 'AlaKhatar al-Tariq) - Surety for Hazards on the Highway}

Dhaman AlaKhatar al-Tariq is a situation in which liability arises against a person who says to another person, take this route, and at the same time he says, it is safe and if you lose any of your property I will compensate you. In this case, the guarantor will be liable for any loss of property by a person who follows his advice. ${ }^{106}$

Such are the conflicts between the views of the two schools of thought. But Ibn Abidin, the author of Rad al-Muhtar, has dealt with this problem in a different way. Under the heading Mustamin or protected person, which forms a chapter of his book, he says that foreign merchants enter into Dar al-Islam or Muslim territory under Aman, that is, a pledge of peace, and transact their business with insurance protection and according to the Islamic Laws. He further adds that when they charter a ship of a Harbi (citizen of a non-Muslim territory), Muslim merchants pay him the freight and also pay a certain amount towards insurance to another $\mathrm{Harbi}$ (insurer) on the condition that he will in return give them compensation for the damage for the goods loaded in the ship. The agent of such an insurer resides in their territory (a Muslim country) as a protected person to receive the amount of insurance and pay the compensation in case of damage. This sort of transaction is not permissible in Islam because it takes place in a Muslim country where Islamic Law, being in force, forbids it. Moreover, it is not permissible for a Muslim to take from the protected person what he is not liable to pay under Islamic Law.

Ibn Abidin then argues that the example of a paid trustee being held responsible for the loss of a thing deposited with him is not applicable to the insurer. This is because the goods insured are not in his possession but in the possession of the owner of the ship or a paid trustee, and he would not be responsible for giving protection against drowning or similar events. The insurer, according to Ibn Abidin, is not responsible for the loss of the goods unless he is convicted of deception. To illustrate this, he cites the example of a person who says to another: "Travel this way and you will be safe." The assurer in this case cannot be held responsible for the property 
of the assured being lost but Ibn Abidin says the case would have been different had the assurer undertaken to pay the loss despite his knowledge of the fact that the way was fraught with danger, for in that case deception will be presumed on his part. Ultimately, the author is of the opinion that if a contract of insurance is entered into between a non-Muslim partner in trade and a Muslim resident in a Muslim country on the one hand, and an insurance company carrying on business in a non-Muslim country on the other, then, if any amount which is realized on the policy is sent to the Muslim partner it will be permissible for him to take it. Here, the contract has been entered into in a non-Muslim country and the person paying the amount of the policy has paid it willingly and without deception, so there would be no objection to its passing to the Muslim. The reverse would be the case if the contract had been entered into in a Muslim country even if the amount is paid in Dar al-Harbi.

More or less the same views were expressed by Shaikh Muhammad Bakhit al-Mutinyi, the Mufti or Jurisconsult of Egypt, when he was asked in the Ottoman regime to give his opinion on this subject. The letter that contained his reply was printed and published by the Nile Press in Egypt in the year $1324 \mathrm{AH}$ (1906 AD). According to him, bail for property is possible in one of two ways: either in the case of Kafala (suretyship) or in the case of damage to property. The condition of Kafala does not apply to the insurance contract for the damage to insured property which is not caused by the insurance company. There is no case for imposing liability upon the insurer if the insured property is damaged, especially because the causes of liability are deliberated, as observed under Islamic Law. He then resorts to the argument advanced by Ibn Abidin and holds that the insurance contract is void because the insurance company or foreign insurer takes upon himself what is not binding upon him under Islamic Law. In conclusion, he points out that if the insurer pays the compensation in Dar al-Harb and not in Dar al-Islam, it is permissible for a Muslim to take it, because taking the property of a Harbi in a Dar-al Harb with his consent and without any deception is not unlawful, whereas in other cases it is unlawful.

\subsection{GLOBAL MODELS OF TAKAFUL}

The banking system under Shari'ah principles has definitely made considerable progress during recent decades. However, Islamic insurance (Takaful) still has a long way to go before it can acquire global recognition. It is not suggested that Takaful does not have the potential to grow, but its development has been hampered by the general belief amongst Muslims that insurance, particularly life insurance, is not permissible under Shari'ah 
Table 1.4 Performance of the general and family Takaful industries

\begin{tabular}{lccc}
\hline Sector & Market share & Estimated revenues & Growth rate in 2015 \\
\hline General Takaful & $83 \%$ & US\$12.3 bn & $17 \%$ \\
Family Takaful & $17 \%$ & US\$2.6 bn & $(1) \% *$ \\
Total Takaful & $100 \%$ & US\$14.9 bn & $14 \%$ \\
\hline
\end{tabular}

Note: * This is largely due to the effects of the depreciation of local currencies relative to the US dollar. In local currency terms, the family Takaful industries in most countries continue to exhibit positive growth rates.

Source: Milliman Research Report Global Takaful Report 2017.

Law. In response to the above negative attitude, contemporary Islamic Scholars argue that Takaful does not amount to gambling or uncertainty, nor does it clash with the general principles of the Shari'ah. This is because a Takaful is a contract of compensation or guarantee with mutual cooperation against the consequences of a well specified negative event or risk.

However, despite some misconceptions regarding Takaful, there are plenty of Takaful companies in today's world economy established and located in most parts of the world. These organizations provide various types of Takaful coverage:

- general Takaful business (property, engineering, miscellaneous accidents, marine, motoring etc.);

- family Takaful business (education, marriage, haji and umrah, saving plans, life insurance etc.).

The owners of these companies are no doubt the pioneers in the field and they have set a great precedent for the Muslim Ummah. It is hoped that the experience gained will be of considerable assistance in this beneficial trend for future generations of Muslim society.

\subsubsection{Rediscovery of Takaful Models in the 1980s}

Islamic banking has been a recent source of development in financial markets, and Islamic insurance has consequently grown not only on religious grounds but also as an innovative financial instrument. With the increase in complexity and variety of products offered by Islamic banks, insurance is often included in retail banking as a value-added product.

The world's pioneer Takaful operator is the Islamic Insurance Company Ltd of Sudan, which was established in 1979. Malaysia, however, is 
where Takaful currently thrives. With the success of Islamic insurance in Malaysia, Takaful operators have emerged in Brunei, Indonesia and Singapore (Islamic Insurance Pte).

Egypt, like many other Islamic countries, suffers from the common attitude that insurance is unnecessary, or even wrong. Insurance still only accounts for a small fraction of the country's Gross Domestic Product. Insurance companies in Egypt are doing their best to change this status. An insurance company, for example, has run television advertisements every day for the whole month of Ramadan. In the early 1990s, legislation was passed to allow the establishment of completely free market companies. These companies, despite substantial minimum capital requirements and prohibition of foreign shareholders, had a wide spread of shareholders and were improving their international profile. In Morocco the situation is very similar, and the Moroccan insurance market has performed poorly.

The Lebanese insurance market, on the other hand, is easily the most sophisticated and open in the region, and insurance awareness is high among the general public, who tend to be well educated,. Much of the market growth, however, is due to the upsurge in medical insurance in the absence of a government health care scheme. The need to educate the Muslim population on the importance of insurance and on the availability of insurance products conforming to the needs of Muslims is thus evident. The Academic Council of the Muslim World League, after making the appropriate modification to comply strictly with the principles of Shariah Law, reached the conclusion that the cooperative form of insurance is acceptable and should be considered an alternative to conventional insurance. The modified cooperative insurance, commonly referred to as Takaful, is becoming increasingly available in countries with a significant Muslim population. Mr Richard Thomas, a Takaful expert who heads the Islamic Investment Banking Division of the United Bank of Kuwait in London, predicts that the growth of Islamic insurance will be rapid over the next 5 to 10 years in line with the fast development of the Islamic investment and banking system. It is, thus, useful to understand the nature of Takaful and to compare it with a conventional insurance contract.

In the same way as in conventional insurance, there are different models for practicing Takaful insurance (IAIS \& IFSB, 2006). Ali (2016) writes that some contentious issues related to Shariah compliance continue to affect the different Takaful models currently in use and require serious attention. Finding an ideal Takaful model is a must for Shari'ah scholars, researchers and industry players. The question of the optimal structure of the Takaful model is an unresolved issue. Takaful operators often face a double dilemma, with investors looking to see profitability in line with 
conventional insurers, while consumers expect to find a product that fully embraces the ideals of solidarity (Global Advisors, 2016).

As part of the development of the guiding principles, the Islamic Financial Services Board (IFSB) conducted its own survey to verify its understanding of the different Takaful models used around the world governing the relationship between participants and operators. This exercise confirmed that the most used models, at the time of the development of the IFSB- 8 standard, are the models of companies whose management is entrusted to a Takaful operator that can be found in the Wakala, Mudharabah and hybrid models.

With the pure mutual model, there are also cooperative societies for which the Takaful fund is fully managed and controlled by the company, but this type of structure is rare in the industry for two main reasons. First, cooperative or mutual enterprises are not recognized in the legal systems of a number of Islamic countries. Secondly, and more fundamentally, a new mutual insurance company would hardly be able to meet the capital requirements essential for any insurance company creation. Thus, one of the important roles played by the Takaful operator is to provide adequate capital support to meet these requirements. From the above, it is thus possible to classify Takaful societies into two large subsets that determine the management model used: companies whose management is entrusted to an operator, and cooperative or purely mutual societies.

\section{Companies whose management is entrusted to an operator}

The model used will have an impact on the management, the redistribution of surpluses and the remuneration of the operator. Since the principle of sharing losses and profits applies between the participants, there is necessarily a separation between the shareholders' fund of the Takaful operator and the Takaful fund of the participants. The Takaful fund can be integrated into the company of the Takaful operator, provided that the assets are segregated so that the funds of the Takaful operator can be separated from those of the participants. It can also be created as a company distinct from the Takaful operator or even established as a "window" of a conventional operator. If there is a deficit in the Takaful fund, the Takaful operator must grant an interest-free "honor loan" that will be repaid using future Takaful fund surpluses, or remit contributions from participants. The operator cannot collect a portion of the technical results that remain the property of the participants, except in the case of a refund of a loan of honor previously granted to the Takaful fund. Some models used in practice predict that the Takaful operator may also receive a performance fee deducted from the annual surplus in order to encourage efficient management, even though this practice does not comply with the recommendations of the 
Accounting and Auditing Organization for Islamic Financial Institutions (AAOIFI). An agency problem exists with the models where management is entrusted to an operator. There are two principals, subscribers and shareholders, who do not share the same goals. Asymmetric information can lead to anti-selection and moral hazard phenomena. The anti-selection can be shown by the participants in the selection of the operator as to the content and quality of the guarantee due to imperfect information, or moral hazard. This is because discretionary power is available to the operator on the amount of contributions as well as on investment income. On the operator's side, moral hazard may involve a false statement of risk or risk behavior of participants once the guarantee is granted. Finally, the risk of anti-selection may materialize in the event of guarantees granted automatically to third parties.

\section{Wakala model}

The Wakala is a mandate given by participants to the Takaful operator. According to this model, the participants and the Takaful operator form a principal-agent relationship whereby the Takaful operator acts strictly as a Wakil "agent" on behalf of the Takaful participants as the principal that performs both activities of investment and underwriting. The subscription is made by the "mandator" Muwakil and the management of the Takaful fund is done by the agent. The Takaful operator as an agent will be responsible for managing the Takaful fund as well as the risks being borne by the Takaful fund. In return for the service rendered by the Takaful operator as Wakil, the operator will receive a fixed commission, called Wakala, remunerating management on behalf of the participants. This Wakala commission is usually a percentage of the contributions paid. Wakala fees must be agreed in advance and expressly stipulated in the Takaful Agreement. For the Takaful operator, the management fees must cover the total costs, that is, management fees, distribution costs, including the remuneration of intermediaries, as well as an operational profit margin for the Takaful operator. In this respect, the Takaful operator will be profitable if the Wakala fees collected exceed the management fees incurred. The operator does not participate directly in the risks borne by the Takaful fund, therefore they cannot share possible investment profits.

\section{Mudharabah model}

Mudharabah is a form of contract that combines both the capital and labor factors in order to share profits according to a distribution agreement defined in advance. The initial contract between the two parties specifies how the gains generated by the technical and financial results will be distributed between the operator and the participants. In this model, the 
Takaful operator acts as a Mudarib (business owner) and Takaful participants as Rab el-Mel (capital providers). As Mudarib, the Takaful operator manages both investment and underwriting (risk) activities on behalf of Takaful participants. In return, the Takaful operator is remunerated by a certain percentage of the investment profit and/or the excess subscription, which will normally be indicated explicitly in the Takaful contract. Once the contract is validated, the participants and the operator cannot unilaterally modify the agreed sharing rate of the investment profit and/or the excess subscription. Any financial loss suffered by the investment and underwriting activities shall be borne solely by the Takaful participants as $\mathrm{Rab} \mathrm{el}-\mathrm{Mel}$, provided that the losses are not attributable to negligence or proven management errors of the Takaful operator. Regarding this, the Takaful operator can generally expect to make a profit only by ensuring that the management fee for the Takaful transaction is less than the total share of the investment profits and/or the excess subscription that he could receive. In the case of losses or a zero result, the operator will not be paid for the work done. This model is used in some Takaful operations, but the Shari'ah Supervision Board of the Islamic Development Bank (IDB) does not approve of the Takaful operator taking a percentage of the excess subscription as a surplus of subscription cannot be considered a profit.

\section{Mudharabah-Wakala hybrid model}

Ali (2016) indicates that in view of the significant criticisms of the practice of surplus sharing and the need to award a performance fee to Takaful operators, industry players have developed a new model combining Mudharabah and Wakala, called the "hybrid model". This model is usually used as part of the Takaful family. As part of the Takaful family, the participants' fund is divided into two accounts: the PRF (Participants' Risk Fund) and the PIF (Participants' Investment Fund). The model uses a Wakala contract for PRF management and a Mudharabah contract for PIF management. In this model, the technical surplus is left to the participants while a performance fee can be withdrawn from the PIF in the case of profits or capital gains being realized on the investments. The hybrid model Mudharabah-Wakala is today the most used in Takaful family companies. The Wakala contract is used for underwriting, and the Mudharabah contract is used for Takaful fund investments (Milliman, 2010).

Budd (2016) indicates that this model, recommended by the AAOIFI, enables the advantages of the Wakala and Mudharabah models to be combined. This model is the most widespread in the industry because of the benefits it provides to operators in terms of remuneration. This author specifies that in this model, two contracts are signed between the operator and the participants: a Wakala contract as Wakil of the participants, with 
a fixed remuneration expressed as a percentage of the contributions; and a Mudharabah contract as Mudarib of the participants, with a variable remuneration depending on the financial results. Boulif (2014) recalls that the operator is designated as Wakil for the management of the Takaful fund with regard to insurance activities (underwriting, pricing, management), and as Mudarib as investment manager. As a Wakil, the operator is remunerated by a management commission, whereas as a Mudarib he is remunerated by a share of the realized investment profits. The profit sharing shall be as per agreed in advance in the Mudharabah contract signed between the Takaful operator and the participants. Douceret (2010) recalls that this model is the one most used in the Middle East because it enables operators to benefit from the advantages of Wakala and Mudharabah, using Wakala for technical management and Mudharabah for investment.

\section{Cooperative or purely mutual companies}

According to IAIS \& IFSB (2006), these companies, regardless of their legal form, are managed on a purely cooperative or mutual basis by and on behalf of the Takaful participants. The company belongs to the participants and the funds are managed and controlled completely by the company. The cooperative model is the only one allowed in Saudi Arabia, which has become the largest Takaful insurance market after the conversion of its insurance sector and the introduction of the Supervision Insurance Companies Act in 2003. In Saudi Arabia, Takaful insurance is supervised by the Saudi Arabian Monetary Agency (SAMA) and governed by the Cooperative Insurance Companies Supervision Act which was issued by Royal Decree $(32 / \mathrm{m})$ in 2003 , in addition to a number of rules and regulations. This insurance market is based entirely on a model of cooperative insurance, as defined in the statutes of the National Company for Cooperative Insurance (Tawuniya), which was the state monopoly company. The law - which does not mention the term Takaful-stipulates that a minimum of 10 percent of the net excess of an insurer must be returned each year to the insured (directly or in the form of a reduction of premiums for the next year). However, this model as defined by Saudi Law remains conceptually different from Takaful insurance; although the concept of redistribution of surpluses is taken into account, it does not include provisions relating to:

- the separation of the funds of the participants and those of the shareholders;

- the obligation to invest in accordance with the rules of Islamic finance; 
- the establishment of a Shari'ah supervisory board as recommended by the AAOIFI and IFSB standards in force.

Nevertheless, most Saudi insurers, if not all, offer general and family Takaful products in accordance with current standards. This country represents, according to ICD-Thomson Reuters, 38 percent of the global Takaful market with $\$ 14.2$ billion of contributions in 2015 .

\subsection{THE MODEL STRUCTURES ( $U Q U D$ ) OF TAKAFUL PRACTICES}

It is generally known that today's Takaful practice is based on the contract of profit and loss sharing (Aqd al-Mudharabah) and a unilateral contract of donation (Aqd al-Tabarru'). Nevertheless, a closer look may reveal some other categories of Shari'ah-justified nominated contracts (Uqud), which possibly directly or indirectly facilitate Takaful operations. In this section, an attempt is made to discover the possible forms (Uqud) involved in Takaful practices.

\section{العقد (al-'Aqd) - Contract}

In Takaful practice, the parties involved are mainly the participants and the operator, who bind themselves with a mutual consent to encounter a well-defined risk. Parties bind themselves relying on the principles of al-'Aqd (contract) through that of al-Ijab (offer) and a Qabul (acceptance). For example, the participants offer to contribute a particular sum of money to the Takaful fund, while the Takaful operator accepts the offer with a view to managing the fund properly and providing a reasonable coverage for the insured against a well-defined risk. Thus, in the Takaful operation the operator binds himself unilaterally to managing the fund properly. 107

\section{المضاربة (al-Mudharabah) - Profit and Loss Sharing 108}

The nature of al-Mudharabah (profit and loss sharing) practices is that of a financial contract whereby the one party, called Rabbul-mal, provides funds to the other party, called Darib, who undertakes to manage the fund through investment or trade and generate profits. For those profits both the Rabbul-mal and also the Darib share are in a pre-agreed proportion. Al-Mudharabah is the primary principle, which is adopted by the Takaful operator as an alternative to the principle of al-Riba. 
For example, ${ }^{109}$ the participants in the Takaful operation contribute a sum of money to the Takaful fund in which the participants are like Rabbulmal, while the Takaful operator is like Darib, who agrees to manage the fund with a view to making a profit which both the participants and the operator share proportionately, no matter whether a defined risk has run on the subject matter or not. ${ }^{110}$

\section{المشاركة (al-Musharakah) - Partnership}

Al-Musharakah is probably a new term originating from the idea of Shirkah (partnership), which has been adopted by contemporary Islamic financial institutions. Al-Musharakah is an agreement between two or more parties to operate a particular business in which all parties contribute to the capital in view of legitimate profit. In other words, in al-Musharakah dealing, the parties involved therein share the liability, profit, and also loss according to their agreement. ${ }^{111}$

The involvement of the contract of al-Musharakah in Takaful operations is quite clear. In a Takaful operation, both the participant and the Takaful operator are mutual partners in the Takaful fund, in which both partners' chief objective is to contribute (contribution and providing a management skill) towards ensuring financial security against a defined risk. In a Takaful operation, both partners (participants and operator) also share the agreed benefit from the Takaful fund.

\section{(al-Bay’ Bithaman al-Ajil) - Sale by Deferred Payment}

In practice, the principle of Bay' Bithaman Ajil (BBA) is that it is a credit sale by deferred payment in which one party buys an asset or property and sells it to the customer at an agreed cost, plus a mark-up price to be paid in the future, either as a lump sum or by installments. ${ }^{112}$ The basic principle of Bay' Bithaman Ajil is therefore based on a mutual contract between the seller and the customer.

Takaful is a doctrine that also involves a contract such as Bay' Bithaman Ajil. For example, in Takaful operation the participants buy the risk from the Takaful operator by paying the agreed contributions and selling it back again to the Takaful operator (upon the occurrence of a defined risk) with costs plus a mark-up price, which means the operator will ultimately pay to the insured or beneficiaries the cost (paid contributions) plus a markup. The payment by participants for the risk could either be lump sum (in short-term policies or general policies) or by installments (in life or longterm policies). 


\section{(al-Salam) - Sale by Deferred Delivery}

Al-Salam is a kind of sale that is practiced based on the general principles of contract of sale, in which the buyer pays for the goods in advance while the goods are to be delivered later. For a valid contract of al-Salam, it is essential that the subject matter (goods) must be in existence at the time of the bargain. 113

There is also relevancy of a contract of al-Salam in a Takaful operation. For instance, the participants in a Takaful operation pay regular agreed contributions to the operator for the security or protection against a welldefined risk, in which the operator receives the money in advance, but he will deliver the object (benefits or protection or security) against a defined risk in the future. Furthermore, once the risk is defined in the agreement between the participants and the operator, it makes a contract of Takaful resembling that of a valid al-Salam contract, in the respect that the latter requires the object or the goods of the contract to exist at the time of the contract. Therefore, there is no element of Gharar (uncertainty) involved in a Takaful operation.

\section{البيع (al-Bay') - Sale}

Bay' is a contract of sale in which a person sells a define good or property with the free consent of another party for a certain price. Both the buyer and the seller in the contract of sale are bound by their promises by way of Ijab (offer) and Qabul (acceptance). ${ }^{114}$

The Takaful operation involves the principles of Bay'. This is because in a Takaful practice the participants and the operator mutually agree that the participants will buy (through paying the contributions) the financial securities against the defined risk from the Takaful operator once the risk runs over the subject matter. Thus in a Takaful practice the participant is like the buyer, while the operator resembles the seller in a contract of sale (Bay').

\section{التبرع (al-Tabarru’') - Donation, Charity, Gift}

Tabarru' means gift or donation, which is given by one person to another without seeking any return. A Tabarru' is made based on the general principles of a contract in which the person that makes it binds themself unilaterally by offering something valuable for the noble cause of welfare of others. ${ }^{115}$

In a Takaful operation the element of contract of al-Tabarru' is directly involved. For example, participants' contributions are credited mainly to 
two accounts: the Participants' Account (PA) and the Participants' Special Account (PSA).

The amount credited to the PSA is regarded as Tabarru', which is managed by the Takaful operator to provide security for others who deserve it. In other words, the participants are unilaterally bound to pay the amount into the PSA from which they themselves are not entitled to seek any benefit.

\section{الوديعة (al-Wadiyah) - Deposit}

Al-Wadiyah is a kind of contract whereby a person leaves his valuables in the custody of others as a trust for safe-keeping. ${ }^{116}$ The elements of alWadiyah involve the practices of Takaful as the participants pay regular contributions to the fund. This is like a deposit entrusted to the operator for safe-keeping in view of better management of the fund and also to provide security against a defined risk. Therefore, in a Takaful operation, both the participants (as depositors) and operator (as the trustee) are also bound by the contract of al-Wadiyah.

\section{الأمانة (al-Amanah) - Trust}

Al-Amanah means "trust", which is also a kind of contract whereby a person offers something valuable to someone else for safe-keeping as a trust. It could sometimes be an implied contract, in which the trustee is unilaterally bound to keep the trust according to the terms and conditions agreed upon by the owner and the trustee.

The basic principle of al-Takaful involves the elements of contract of al-Amanah. This is because the participants paying the regular contributions to the operator is like the trust, which is managed by the operator (as a trustee) according to the terms and conditions. The management by the operator includes the provision to provide financial security in favor of the insured. Therefore, both the participants and the operator are like parties to a contract of al-Amanah (trust).

\section{الجعالة (al-Ju'alah) - Reward for Service}

Al-Ju'alah is a kind of contract for hiring services. In such a contract one party undertakes to pay a specified amount of money to another party for rendering a defined service in accordance with the terms negotiated between them. An example of an al-Ju'alah contract is that a person makes an offer to another person to pay some amount of money if the other person can offer a particular service for the benefit of the former. 
Takaful operation definitely involves the element of the contract of al-Ju'alah. As evidence of this, the participants in the operation make an offer to the operator that they will pay a total amount of contributions to the Takaful fund with a view to making the operator obliged to render the service to the insured through providing financial security against the defined risk. Once the operator accepts the offer of the participants, he will bind himself (operator) to provide the services according to the terms and conditions.

\section{الكفالة (al-Kafalah) - Guarantee}

Al-Kafalah is a contract of bailment, or guarantee. By virtue of Article 612 of the Mejelle, a contract of al-Kafalah is one in which a person assumes responsibility or liability on behalf of another person in respect of demand for something. In this provision, adding the liability or responsibility means a guarantee, which is determined by the principles of contract relating to Kafalah.

Al-Kafalah operation is a kind that also involves the element of contract of al-Takaful. This is because, in a Takaful practice, the participants contribute to the Takaful fund by mutual agreement with the operator that he will undertake to manage the fund properly and will provide financial security against a defined risk once it is (financial security) demanded by the insured. Therefore, the operator is like a guarantor in a contract of Kafalah, which adds to its responsibility or liability to the management of the fund and also to provide the security once it is demanded by the insured according to the terms and conditions.

\section{الو لاء (al-Wala') - Clientage}

Al-Wala' means a contract of clientage between one unknown person and another person, in which the stranger offers to be the other person's guardian and will have to pay a form of compensation if the stranger commits a wrongful act. In consideration of this agreement, the second person is entitled to inherit the property of the other person on the event of death. ${ }^{117}$ If the latter person agrees to the offer made by the stranger, the contract will be binding upon both of them.

There are some similarities between the contract of al-Takaful and the contract of al-Wala'. For example, in a Takaful operation the participants are like strangers who make an offer to the operator that the operator will be liable or responsible against a defined risk faced by the insured to provide financial security for the insured, while the operator will receive the contribution from the participants, which is like receiving an inheritance 
from the property of the participants. ${ }^{118}$ Therefore there is a close relationship between the Takaful contract and a contract of al-Wala'.

\section{الإجارة (al-Ijarah) - Hiring, Employment}

Al-Ijarah is a contract of hiring whereby one person hires another for specified services, in which the hirer is obliged to provide a reward for the services rendered to him. ${ }^{119}$ A Takaful contract involves the element of the contract of al-Ijarah. For example, Takaful participants hire the operator by paying regular contributions whereby the operator undertakes the responsibility to provide the services to the participants, through management of the fund. He also provides financial security for the insured against a defined risk.

\section{الوكالة (al-Wakalah) - Agency}

Al-Wakalah is a contract of agency, in which a person delegates his business to another and substitutes the other in his place. ${ }^{120}$ The person delegated is called Wakil (agent), whose fundamental obligation is to use his skill towards the improvement of assigned job operations. Thus, both the principal and the agent are equally bound by each other under contract of al-Wakalah.

In a Takaful operation those who work for the promotion or development of the products are working like an agent appointed by the operator to offer their skills on behalf of the operator, not only under law of contract but also under contract of al-Wakalah. Therefore, a Takaful operation is not far from the idea of contract of al-Wakalah.

\section{الضمان (al-Dhaman) - Guarantee, Surety}

Al-Dhaman is also a type of contract of responsibility, guarantee, warranty and surety against any form of insurable risk. In a contract of al-Dhaman both the guarantor and also the guaranteed are bound by the terms and conditions. The nature of a contract of al-Dhaman is that a person undertakes to provide security for another against a well-defined risk identified by the subject matter of the contract.

A contract of Takaful resembles an al-Dhaman contract. For example, the participants are guaranteed by the operator, against a defined risk, to provide financial security for the insured in consideration of the contribution paid by the participants. Thus, the operator is like the guarantor, while the insured is like the guaranteed in a contract of al-Dhaman.

Generally, the contemporary Takaful operators in the Global Economy 
adopt in their operations the contracts of al-Mudharabah, al-Wakala and al-Tabarru' and the principle of contract (al-'Aqd). Nevertheless, there are many other types of Shari'ah-justified contracts or rather contractual elements, which may facilitate Takaful operations. It is hoped that the international Takaful industry will have a broader justification with a multiple range of contractual elements in its operations in the 21 st century's sophisticated advanced economic environment.

\section{NOTES}

1. Ikram Shakir, "Tomorrow's Takaful Products", New Horizon, 66, 1997, p. 5.

2. This idea is based on an interview with Dr Abu Said Majid, Department of Arabic, Kulliyyah of IRKH, IIUM.

3. The idea has been developed based on an interview with Mr Ahmad Mazlan Zulkifli, Takaful Consultant, BIRT, Malaysia.

4. Ibid.

5. It is practiced in Malaysia, Sudan and other countries in their Takaful operations.

6. From a discussion with Mr Ahmad Mazlan (see note 3).

7. See al-Qur'an, Surah al-Maidah, 5:2; also The Takaful Act 1984, at S. 2.

8. "Islamic Insurance in Asia: Activities, Problems and Prospects", in Insurance Journal, Vol. 50, 1999, p. 89, at 92 .

9. See generally Billah, M. Ma'Sum, "A Model of Life Insurance in the Contemporary Islamic Economy", in Arab Law Quarterly, 12:3, 1997, at pp. $287 \mathrm{ff}$.

10. This ruling was confirmed by the Fatwa issued by The National Council for Muslim Religious Affairs of Malaysia in 1974, in [1974] 1 MLJ at x.

11. Surah al-Imran, 3:145.

12. See, for example, al-Qur'an, 2:134.

13. Al-Mudharabah is one of the financial techniques in the Islamic partnership dealings between two or more parties whereby one party provides capital while the other offers a service or skill in a particular business, both sharing profits accordingly. Today's Islamic banks and Islamic insurance companies have been operating based on the principle of Mudharabah, which is an alternative to the interest-based transaction. In other words, Mudharabah is a complete interest-free profit and loss sharing transaction.

14. Al-Qur'an, 5:3.

15. Ibid.

16. See generally Billah, M. Ma'Sum, "Life Insurance? An Islamic View", in Arab Law Quarterly, 8:4, 1993, at $317 \mathrm{ff}$.

17. Klingmuller, Ernest, "The Concept and Development of Insurance in Islamic Countries", in Islamic Culture, Vol. 43, January, 1969, at 30.

18. See "Aqilah", in Gibb, H.A.R. et al., The Encyclopedia of Islam, E.J. Brill, Leiden, 1979.

19. See "Aqilah" in Hughes, Thomas Patrick, Dictionary of Islam, Cosmo Publications, New Delhi, India, 1982.

20. See Murghimani, Ali IbnAbiSakar, al-Hedaya (trans. Eng.) Charles Hamilton, The Hedaya, Vol. 4, Book 51, Premier Book House, Lahore, Pakistan, 1982, at 670.

21. See Sahih al-Bukhari (trans. Eng.) Khan, Dr Muhammad Mushin, The Translation of the Meanings of Sahih al-Bukhari, Kazi Publications, Lahore, Pakistan 1979, at 34.

22. See Athqalam, Ahmad IbnHajar, Fathul-Bari, Vol. 12, Alan NashrulKutub Al-Islamiah, Lahore, Pakistan 1981, at 246.

23. Sahih al-Bukhari, op. cit., 9:45, at 34 .

24. Vardit, Rispler, Insurance in the World of Islam, Origins and Current Practice, UMI, USA, 1985, at 28. 
25. Rahim, M.A., Islamic ArthanaitikNirapattawaBinma, (Bangla) Islamic Foundation, Bangladesh, Dhaka, 1983, at 106.

26. The articles of the constitution from 3 to 12 emphasize the payment of blood money relying on the doctrines of Aqilah.

27. See Hamidullah, M., Introduction to Islam, Sh. Muhammad Ashraf, Lahore, 1983, at articles $4-12 \mathrm{a}$, at $42 \mathrm{ff}$.

28. Ibid., at para. 362 , at 146 .

29. Ibid., Art. 3, at 55 .

30. See Hamidullah, op. cit., at articles $4-12 \mathrm{a}$, at $42 \mathrm{ff}$.

31. Islam da DevletButcest, pp. 382-3 as cited by Vardit, op. cit., at fn. 84, at 28.

32. See Aqilah in Gibb et al., op. cit., at $29 \mathrm{f}$.

33. Vardit, op. cit., at $29 \mathrm{f}$.

34. See Klingmuller, op. cit., at 30.

35. Ibid.

36. See Vardit, op. cit., at 32.

37. Ali, K.M. Murtuza, Insurance in Islam: Some Aspects of Islamic Insurance, Islamic Economics Research Bureau, Dhaka, 1991, at 45.

38. See in Gibb et al., op. cit., at 29.

39. Assumes 35 percent to 50 percent of defaults are due to death or disability of the borrower.

40. Al-Qur'an, 5:2.

41. See generally in Rashid, S.K., "Islamization of Insurance-A Religio-Legal Experiment in Malaysia", in Religion and Law Review, 2:1, 1993, at $26 \mathrm{f}$.

42. See in Klingmuller, op. cit., at 35 .

43. See the details in Billah, "Life Insurance? An Islamic View", at 319.

44. See ibid., at 324 .

45. See in Rashid, op. cit., at 27.

46. Al-Qur'an, 2:201.

47. Al-Qur'an, 4:29.

48. See Takaful Cover, Syarikat Takaful Malaysia Sdn Bhd., Kuala Lumpur (n.d.).

49. Shamsuddin, Haji Azlan Khalili Hj., Banking and Public Finance in Islam, Dewan Pustaka Fajar, Kuala Lumpur, 1988, at 13.

50. Al-Qur'an, 3:130.

51. See Shafi, Maulana Mufti Muhammad et al., BimahJendegi (trans. Urdu-Eng.), Meenai, Anwar Ahmad, Life Insurance, Darul Isayat, Karachi, 1995, at 36.

52. See the judgment of Suffian, J., in Reman bin Mihat (1965) 2 MLJ 1.

53. See the decision of the High Court of Karachi in Karim vs. Hanifa (1970) PLD 683.

54. See in Billah, "Life Insurance? An Islamic View", at 319.

55. The Takaful Act (Malaysia) 1984, at S. 2.

56. Ibid., at S. 64.

57. Al-Qur'an, 5:2.

58. Siddiqi, M.N., Insurance in an Islamic Economy, The Islamic Foundation, UK, 1985, at 67 .

59. Ibid.

60. See The Takaful Act (Malaysia) 1984, at S. 2.

61. See the Fatwa of Sheikh al-Azhar in Iqtisad al-Islam, 1995, at p. 60.

62. Rules of the Shari'ah Advisory Board, Sudan, at p. 11.

63. Ibid., at 37.

64. See The Takaful Act (Malaysia) 1984, at S. 8(5) (b).

65. See The Insurance Act (Malaysia) 1996, at S. 167(1).

66. Cf. The Takaful Act (Malaysia) 1984, at S. 64.

67. The Insurance Act (Malaysia) 1996, at S. 166(1).

68. Al-Qur'an, 2:42.

69. See The Fatwa in (1994) 1MLJX.

70. Al-Qur'an, 5:2. 
71. The Insurance Act (Malaysia) 1996, at S. 166(1).

72. Al-Qur'an, 3:28.

73. Muwatta al-Malik, 44:2.

74. Coulson, N.J., A History of Islamic Law, Routledge, 2017, pp. 93-4.

75. Washington Irving, Mohamed and his Successors, Darf Publishers Ltd, London, 1985.

76. Al-Qur'an, 47:4.

77. Al-Qur'an, 9:6.

78. Al-Mawsuah al-Fiqhiah, Vol. 18, p. 84.

79. Ibid.

80. Newby, G., A Concise Encyclopedia of Islam, Oneworld Publications, 2013, p. 135.

81. Sadi Abu Habib, al-Kamus al-FiqhiLukatanwaIstlahan, p. 389.

82. Ibid.

83. Ibid.

84. Al-Qur'an, 47:11, Abdullah Yusuf Ali (trans.), The Meaning of The Holy Qur'an.

85. Al-Mawsuah al-Fiqhiah, Vol. 29, p. 221.

86. Ibid.

87. Sahih al-Bukhari (trans. Eng.) by Khan, Dr M. Muhsin, op. cit., Vol. 9. Kitab al-Diyat, No. 45 , p. 34.

88. Al-Mawsuah al-Fiqhiah, Vol. 29, p. 221.

89. Gibb, H.A.R. and Kramers, J.H. (eds), Shorter Encyclopedia of Islam, South Asian Publishers, Karachi, 1981, p. 29.

90. Ibid.

91. Ibid.

92. Al-Mawsuah al-Fiqhiah, Vol. 29, p. 223.

93. Abu Dawud, Vol. 3, p. 320: cited in al-Mawsuah al-Fiqhiah, Vol. 29, p. 226.

94. Vardit, op. cit., pp. 29-31.

95. Radal-MuhtarAla al-Durial-Mukhtar, Vol. 6, pp. 280-82. It is also cited in Muhammad Muslehuddin, Insurance and Islamic Law, 1995, pp. 148-50. Also in al-Tamin al-Tigari, pp. $238-40$.

96. Anwar, Ahmad Meenai (trans.), Life Insurance, op. cit., p. 48.

97. Klingmuller, E., op. cit., at 30.

98. Ibid.

99. Ibid.

100. Ibid.

101. Encyclopedia of Islam, p. 105.

102. Al-Qur'an, 4:58, Abdullah Yusuf Ali (trans.) The Meaning of The Holy Qur'an.

103. Al-Tamin al-TigariWa al-Badil al-Islami, p. 226, Dar al-Itisam.

104. Al-Qur'an, 12:72, Abdullah Yusuf Ali (trans.), The Meaning of The Holy Qur'an.

105. Al-Tamin al-TigariWa al-Badil al-Islami, p. 226, Dar al-Itisam.

106. Ibid.

107. This is based on the discussion with Mr Ahmad Mazlan Zulkifly, Takaful Consultant, BIRT, Kuala Lumpur.

108. See generally in Yusuf Talal Delorenzo (ed.), A Compendium of Legal Opinions on the Operations of Islamic Banks, IIBI, London 1997, at pp. 171-220.

109. Islamic Banking Practice from the Practitioners' Perspective, BIMB, 1994, p. 22.

110. For further discussion see Chapter 2 of this work under the heading, "Principles of al-Mudharabah and al-Musharakah".

111. See Muhammad Akram Khan, Glossary of Islamic Economics, Mansell, London, 1990, p. 100.

112. Ahmad Ibrahim, "Legal Framework of Islamic Banking", in IKIM Law Journal, 1:1, July-December, 1997, p. 1, at 4. It is further noted that at present the doctrine of Bay' Bithaman Ajil is practiced in Malaysia by installment only. But of course there is no restriction so far in the Shari'ah for the buyer in a Bay' Bithaman Ajil transaction to choose whether to settle the payment as a lump sum or by installment.

113. Muhammad Akram Khan, op. cit., p. 20. 
114. Ibid., p. 13.

115. Ibid., p. 29.

116. Al-Zabyidi Mohammad, TajulAroos, Vol. 2, Kuwait, 1967, p. 591.

117. KashfulQana, Vol. 4, p. 498.

118. This argument may only be applicable in a life policy upon the occurrence of the death of the insured.

119. Wahbah Zuhaily, Al-Fiqh Al-Islamy Wa Adillatuh, Vol. 4, Dar El-Fikr, Qahirah, 1996, p. 729.

120. Muhammad Akram Khan, op. cit., p. 140. 